\title{
Testing for causality between FDI and economic growth using heterogeneous panel data $^{1}$
}

\author{
Melisa Chanegriha ${ }^{2}$ \\ Middlesex University, London, UK \\ Chris Stewart ${ }^{3}$ \\ Kingston University, London, UK \\ Christopher Tsoukis ${ }^{4}$ \\ Keele University, Staffordshire, UK
}

May 2018

\begin{abstract}
In this paper we investigate the causal relationship between the ratio of FDI to GDP (FDIG) and economic growth (GDPG). We use innovative econometric methods which are based on the heterogeneous panel test of the Granger non-causality hypothesis based on the works of Hurlin (2004a), Fisher (1932, 1948) and Hanck (2013) using data from 136 developed and developing countries over the 1970-2006 period. According to the Hurlin and Fisher panel tests FDIG unambiguously Granger-causes GDPG for at least one country. However, the results from these tests are ambiguous regarding whether GDPG Granger-causes FDIG for at least one country. Using Hanck's (2013) panel test we are able to determine whether and for which countries there is Granger-causality. This test suggests that at most there are three countries (Estonia, Guyana and Poland) where FDIG Granger-causes GDPG and no countries where GDPG Granger-causes FDIG.
\end{abstract}

JEL classification: C33; F21; F43; N10;

Keywords: Granger-causality Tests; Panel Data; FDI; Economic Growth;.

\footnotetext{
${ }^{1}$ The authors gratefully acknowledge Jalal Siddiki's helpful comments on an earlier version of the paper.

${ }^{2}$ Chanegriha: Economics and International Development, Business School, Middlesex University, Hendon campus, The Burroughs, London NW4 4BT, UK; m.chanegriha@mdx.ac.uk.

${ }^{3}$ Stewart: School of Law, Social and Behavioural Sciences, Kingston University, Penrhyn Road, Kingston upon Thames, Surrey KT1 2EE, UK; c.stewart@kingston.ac.uk.

${ }^{4}$ Tsoukis: Address: Economics and Finance, Keele Management School, Keele University, Staffordshire, ST5 5BG, UK; email: c.tsoukis@keele.ac.uk
} 


\section{Introduction}

With the sharp rise in Foreign Direct Investment (FDI) flows since the 1990s, questions have arisen as to its relation to host countries' output and growth (Chowdhary and Mavrotas, 2005; Ghosh and Wang, 2009). A range of analyses have emphasised the beneficial effects of incoming FDI: It can potentially contribute to economic growth through new capital investment, technology transfer, development of human capital and skills, integration into global economic networks and strengthening of the competitive environment in a host country(De Mello, 1997, 1999; Blomstrom et al.,1992, 1996; Borensztein et al., 1998). ${ }^{5}$ At the same time, the host country's GDP and market size is one of the key determinants of incoming FDI itself (Chanegriha, Stewart and Tsoukis, 2017). Understanding the direction of causality between the GDP and FDI is crucial for formulating public policies that encourage private investors in developing countries. A finding that FDI has a positive impact on growth would imply that policy makers should focus on policies that have been shown to promote FDI such as school attainment, openness to international trade, lower taxes and inflation (Asiedu, 2002; Chakrabarti, 2001; Chanegriha, Stewart and Tsoukis, 2017); whereas, if FDI does not cause growth, such policies would need to be reconsidered. In terms of theory, a non-causality result would also cast doubt on the validity of the theories that have stressed the beneficial effects of FDI for the host country. While there is a pool of empirical studies regarding the relationship between FDI and economic growth, discussed below, the results are mixed. We still concur with Caves (1996) who early on suggested that "the causal relationship between FDI and economic growth is a matter on which we totally lack trustworthy conclusions". This is an unsatisfactory state of affairs for both theory and public policy.

This paper tests the direction of causality between FDI and economic growth. Our work contributes to the literature in the following ways. First, we apply the tests to a larger panel of countries than previously considered in the literature. Our panel analysis uses pooled data from 136 developed and developing countries for 1970-2006. Existing studies that test Granger non-causality (GNC) between GDP and FDI apply this test on time-series data for a single or small group of countries. By contrast, this paper analyses pooled data for a large number of countries over a relatively long period to exploit both cross-sectional and time-

\footnotetext{
${ }^{5}$ There may also exist drawbacks for the host country, e.g. a deterioration of the trade balance (the flip side of the improvement of the capital account) and crowding out of domestic investment.
} 
series dimensions of the data. Second, in addition to applying standard time-series GNC tests we also apply a battery of panel GNC tests by utilising recent advances in the relevant methodology. These include the traditional Fisher $(1932,1948)$ method and the recent Hurlin (2004a) test. We are not aware of any previous application of Hurlin's (2004a) method to the causality between FDI and growth in the literature. Also, we adapt the panel method applied by Hanck (2013) within the context of unit root testing to test for GNC. This panel method is robust in the face of cross-sectional dependence and can identify which individual units (countries) reject the null hypothesis of interest and those that do not. We are not aware of any previous application of this method to GNC testing. The battery of tests and the large sample aim at obtaining an holistic view and are both motivated by the conflicting results in extant literature. Finally, in all panel tests that we employ, we allow for the least restrictive specification, thus avoiding erroneous general inferences.

Empirical work on the FDI-growth relationship has utilised a variety of samples, methodologies and conditioning factors (e.g., financial markets, technological development, openness, regulatory environment, human capital, labour markets and more). The studies may be grouped into three categories according to their results. Some find a positive unconditional effect of FDI on growth -Blomstrom et al. (1996); Gao (2001) and Lensink and Morrissey (2006). Others find an ambiguous role for FDI alone on economic growth and find an important role for various conditioning factors that promote the beneficial effects of FDI Borensztein et al. (1998), Campos and Kinoshita (2002), OECD (2002), Alfaro et al. (2004), Busse and Groizard (2008), Agrawal (2000). The problem with this class of studies is that they do not reach any consensus as to what are the most important conditioning, or facilitating, factors. A third category does not find any positive effect of FDI on growth, even taking into account conditioning factors as above -Carkovic and Levine (2005) and Mencinger (2003). ${ }^{6}$ Thus, all considered, the lack of any robust conclusions is the only safe conclusion on the FDI-growth relationship. In addition, the role of economic growth as an important determinant of FDI inflows into host countries, mentioned above, suggests a possible dual causality of FDI to growth (Choe, 2003).

\footnotetext{
${ }^{6}$ See Chowdhury and Mavrotas (2005)and Ozturk (2007) for surveys of the FDI and growth relationship. Mody and Murshid (2002) discusses the relationship between domestic investment and FDI. See Asiedu (2003) for an excellent discussion of the relationship between policy reforms and FDI in the case of Africa. Gorg and Greenaway (2004) analyse the effects of FDI on domestic firms.
} 
Yet a fourth strand of literature investigates Granger-causality between GDP and FDI. Causality tests also fail to reach unanimous conclusions. There seem to be those that find causality to run (mostly) from FDI to GDP, such as Chan (2000), Duttaray (2001), Zang (2001), OECD (2002). However, the strength of the causal effect varies considerably, as do the conditioning factors. Other studies report reverse causality, from GDP to FDI, e.g. Chakraborty and Basu (2002), Choe (2003), Ozturk and Kalyoncu (2007), Sooreea-Bheemul and Sooreea (2013); again, the details vary considerably, e.g. some may find mixed results across different countries, or bi-directional causality with one direction more prominent, etc. Yet others find no significant causality (Ericsson and Irandoust, 2001), or very mixed results (Gursoy et al., 2013) or even negative causality (Mencinger, 2003, which found a negative causal relationship between FDI and GDP implying that FDI hampered the real convergence of Eastern European countries with the rest of the EU). One conclusion that may follow from such disparate results is the need to continue testing by employing larger data sets and more general methods; this motivates this study.

Apart from the very diverse country experiences and samples, what may account for such discrepancy in the results? Criticisms of the empirical approaches have been directed against the use of time averaged data, resulting in loss of information and bias (Greene, 2000); the reliance on GDP growth rates, i.e. first differences, resulting in misleading inferences regarding long run relationships (Ericsson et al., 2001); the potential of endogeneity bias resulting from reverse causality (see Parsons and Titman, 2007).

Our methodology applies panel GNC tests to exploit the enhanced power of panel data methods. These methods are based on Fisher (1948), Hurlin (2004a), and Hanck (2013). Endogeneity is not an issue in our causality tests because the regressors are all lagged variables. Further, we do not average our data and therefore avoid the issues associated with this. In our analysis we assume that FDI/GDP and GDP growth are stationary. In the former case, we do not expect FDI and GDP to diverge without bound while in the latter we believe that GDP growth is intrinsically stationary. Owing to the relatively short time-series for many countries we cannot consider error correction models and so limit the analysis to two stationary series. Finally, our use of panel data should help increase the power of the tests. ${ }^{7}$

\footnotetext{
${ }^{7}$ In our estimation we do not need to distinguish between a group of developed and a group of underdeveloped countries because Hanck's (2013) method allows us to identify whether Granger-causality exists for each individual country.
} 
The rest of the paper is organised as follows. Section 2 presents the econometric methodology and data. Section 3 presents and discusses the empirical results; we conclude in Section 4.

\section{Econometric Methodology}

We test for GNC (Granger, 1969, 1980) between two variables, the FDI-GDP ratio and GDP growth, using heterogeneous panel data. First, we apply standard time-series GNC tests for each country. Second, our panel tests are based upon pooling the time-series results to exploit the panel properties of data and allow the coefficients to vary across countries. Within this broad framework, we apply three panel GNC tests based on Hurlin (2004a, 2008), Fisher (1948) and Hanck (2013). These panel tests develop Holtz-Eakin et al's (1988) method by allowing the coefficients to be different across sections. We consider the most general case of heterogeneous slopes and intercepts, thus avoiding the pitfall of making erroneous generalised inferences across the entire cross-section which might in fact be true only in a subset of countries (Hood and Irwin, 2006). Hurlin (2004b, 2008) and Hurlin and Venet (2001) developed Granger-causality tests to take into account cross-sectional heterogeneity in panel data (unbalanced or balanced). Hence, they distinguished between the heterogeneous noncausality (HENC) and homogeneous non-causality (HNC) hypotheses.

\subsubsection{The Hurlin and Venet GNC method}

Hurlin and Venet (2001) and Hurlin (2008) consider two covariance stationary variables, denoted $x_{i, t}$ and $y_{i, t}$, observed on $t=1,2, \ldots, T_{i}$ periods and $i=1,2, \ldots, N$ individuals (where for a balanced panel $T_{i}=T$ ) in a linear bivariate heterogeneous panel vector autoregression (VAR) of the following form:

$x_{i, t}=\alpha_{i}+\sum_{H=1}^{H_{i}} \gamma_{i}^{(H)} x_{i, t-H}+\sum_{H=1}^{H_{i}} \beta_{i}^{(H)} y_{i, t-H}+\varepsilon_{i, t}$

The lag-length $H_{i}$ can be different for different cross-sectional units, however, when $H_{i}=H$ the lag-lengths are identical for every cross-section. Individual coefficients, $\alpha_{i}$, are 
considered fixed while the slope coefficients, $\gamma_{i}{ }^{(H)}$ and $\beta_{i}^{(H)}$, vary across units. Equation (1) is estimated by ordinary least squares (OLS) for each cross-sectional unit. The time-series GNC null for each individual unit is $\beta_{i}^{(1)}=\cdots=\beta_{i}^{\left(H_{i}\right)}$ and can be tested using the standard time-series F-statistic, $F_{i}$, which has an $F\left(H_{i}, T_{i}-2 H_{i}-1\right)$ distribution. Hurlin and Venet (2001, p. 14) demonstrate that the corresponding time-series Wald statistic is $W_{i}=H_{i} F_{i}$ that asymptotically (as $T_{i} \rightarrow \infty$ ) has a $\chi^{2}\left(H_{i}\right)$ distribution.

The corresponding null hypothesis $\left(H_{0}\right)$ for the whole panel is homogeneous non-causality (HNC), which is expressed as:

$H_{0}: \beta_{i}^{(1)}=\cdots=\beta_{i}^{\left(H_{i}\right)}=0, \quad \forall i$

The alternative hypothesis $\left(H_{1}\right)$ is that $y_{i, t}$ Granger-causes $x_{i, t}$ for at least one cross-section. That is, there are $N_{1}(<N)$ individual units with no causality from $y_{i, t}$ to $x_{i, t}$, and $N-N_{1}$ individuals where $y_{i, t}$ Granger-causes $x_{i, t}$, thus:

$H_{1}:\left\{\begin{array}{c}\beta_{i}^{(1)}=\cdots=\beta_{i}^{\left(H_{i}\right)}=0, \quad i=1, \ldots, N_{1} \\ \beta_{i}^{(1)} \neq 0 \cup \ldots \cup=\beta_{i}^{\left(H_{i}\right)} \neq 0 \quad i=N_{1}+1, \ldots, N\end{array}\right.$

When $0<N_{1}<N$ the causality relationship is heterogeneous across individual units.

Hurlin (2004a, p. 14) demonstrates that provided $T_{i}>5+2 H_{i}$ the following normalised average Wald statistic has a standard normal distribution as $N$ tends to infinity and is appropriate for fixed (small) $T$ (semi-asymptotic) $:^{8}$

$$
\begin{aligned}
\tilde{Z}_{N ; T}^{H N C}=\sqrt{N}\left[W_{N, T}^{H N C}(\varphi)-N^{-1} \sum_{i=1}^{N} H_{i}\right. & \left.\times \frac{\left(T_{i}-2 H_{i}-1\right)}{\left(T_{i}-2 H_{i}-3\right)}\right] \\
& \times\left[N^{-1} \sum_{i=1}^{N} 2 H_{i} \times \frac{\left(T_{i}-2 H_{i}-1\right)^{2} \times\left(T_{i}-2 H_{i}-3\right)}{\left(T_{i}-2 H_{i}-3\right)^{2} \times\left(T_{i}-2 H_{i}-5\right)}\right]^{-\frac{1}{2}}
\end{aligned}
$$

where,

\footnotetext{
${ }^{8}$ The panel test statistic is not always positive, although it is based on individual Wald statistics that are all positive, because the expected value of these statistics is subtracted in constructing the normalised $\mathrm{Z}$ statistics. Nevertheless, the test is one-tailed because only very small values of Wald statistics will fall in the extreme left hand tail and these will indicate non-rejection of the null. Hence, the rejection region only occurs in the right hand tail. For extensive and full derivations of asymptotic and semi-asymptotic distributions, see Hurlin (2008).
} 
$W_{N, T}^{H N C}(\varphi)=\frac{1}{N} \sum_{i=1}^{N} W_{i, T}$

such that $W_{i, T}$ is the Wald statistic for cross-section $i$.

The above statistic, $\widetilde{Z}_{N ; T}^{H N C}$, is appropriate when the panel is unbalanced ( $T_{i}$ varies across units) and the lag lengths $\left(H_{i}\right)$ in each cross-section's VAR are different. ${ }^{9}$

When $\tilde{Z}_{N ; T}^{H N C}$ exceeds its critical value the HNC null is rejected and the alternative that at least one cross-sectional unit exhibits Granger-causality (GC), cannot be rejected. Otherwise, the HNC null cannot be rejected and all cross-sectional units satisfy GNC.

Hurlin (2008, pp. 15 - 17) reports Monte Carlo simulation experiments that demonstrate that the semi-asymptotic panel statistic (fixed $T$ and large $N$ ), $\tilde{Z}_{N ; T}^{H N C}$, is virtually correctly sized for all values of $T$ and $N$. Further, these semi-asymptotic panel statistics, which are approximately correctly sized, exhibit substantially greater power than the Wald statistics that are calculated for a single time-series. This is true even when $N$ is small. "This improvement in power can be intuitively understood as follows. Individual statistics are bounded from below (by zero) but may take arbitrarily large values. Hence, when averaging among individual Wald statistics, the 'abnormal' realisations (realisations below the chisquared critical value) are annihilated by the realisations on the true side (large)." Hurlin (2008, p. 16). The power of the panel statistic is slightly lower when there is Grangercausality for some cross-sectional units in the panel and not others. Nevertheless, power is regarded as "reasonable" even when $T$ and $N$ are small and when there is causality for only a very small percentage of cross-sections (which is the worse case scenario in terms of power).

When $T$ and $N$ are very small there is some slight size distortion as $H$ rises which means that the statistics are not very near to the standard normal distribution and critical values from this distribution can be improved upon. Hurlin (2008, p. 18) suggests that the critical value, $\tilde{C}_{N, T}(\alpha)$, for the semi-asymptotic panel statistics (based on a balanced panel and constant $H$

\footnotetext{
${ }^{9}$ When the panel is balanced and the lag lengths are the same in each cross-section's VAR a simplified panel test statistic may be employed - see Hurlin (2008).

${ }^{10}$ This is suggested to be true, for example, when $N=5$. This is so even when the time-series is around 50 observations, a typical size for annual macroeconomic time-series.
} 
across sections) can be approximated by the following expression:

$\tilde{C}_{N, T}(\alpha)=Z_{\alpha} \times \frac{(T-2 H-1)}{(T-2 H-1)} \times \sqrt{\frac{2 H}{N} \times \frac{(T-2 H-3)}{(T-2 H-5)}+} \frac{H \times(T-2 H-1)}{(T-2 H-3)}$

where, $Z_{\alpha}$ is the critical value taken from the standard normal distribution for the $\alpha$ level of significance.

Hurlin (2004a) does not provide the formula for calculating critical values when the panel is unbalanced ( $T_{i}$ varies across units) and the lag lengths $\left(H_{i}\right)$ in each cross-section's VAR are different (for the panel statistic given by (4)). However, from the equations reported in Hurlin (2004a) as (13), (14), (17) and (20) the formula for obtaining the critical value appears to be: ${ }^{11}$

$\tilde{C}_{N, T}(\alpha)=Z_{\alpha} \sqrt{N^{-2} \sum_{i=1}^{N}\left[2 H_{i} \times \frac{\left(T_{i}-2 H_{i}-1\right)^{2} \times\left(T_{i}-2 H_{i}-3\right)}{\left(T_{i}-2 H_{i}-3\right)^{2} \times} \frac{\left(T_{i}-2 H_{i}-5\right)}{2}\right.}+N^{-1} \sum_{i=1}^{N}\left[H_{i} \times \frac{\left(T_{i}-2 H_{i}-1\right)}{\left(T_{i}-2 H_{i}-3\right)}\right]$

This panel GNC test's advantages include improved efficiency due to the increased sample size of the test and substantially greater power compared to its time-series counterpart (even for small $T$ and $N) .{ }^{12}$ The testing procedure is simple to implement being based on averages of Wald statistics obtained from time-series regressions and the model allows for heterogeneity in all coefficients across the individual units and for heterogeneity in terms of which cross-sections exhibit GNC. The two main drawbacks of this procedure are as follows. "Firstly, the rejection of the null of Homogeneous Non-causality does not provide any guidance as to the number or the identity of the particular members for which the null of non-

\footnotetext{
${ }^{11}$ Alternatively, one can group countries into the value of $N, T_{i}$ and $H_{i}$ used in the test and identify the critical value appropriate for each group using (6). To obtain the critical value for the whole panel one can take the weighted average of these group critical values where the weights reflect the proportion of cross-sectional units from the whole panel appearing in each group.

${ }^{12}$ Hurlin and Venet (2008, p. 11) provide the following commentary within the context of bivariate GNC tests between financial development and GDP growth. "What is the main advantage of this Granger non-causality test? For instance, let us assume that there is no causality from financial development to growth for all of the $N$ countries. Given the Wald statistics properties in small sample[s], the analysis based on $N$ individual tests is likely to be inconclusive. With a small $T$ sample, some of the realizations of the individual Wald statistics are likely to be superior to the asymptotic critical values of the chi-square distribution. These 'large' values of individual statistics lead to wrongly reject the null hypothesis of non-causality for at least some countries. The conclusions are then no[t] clear cut. On the contrary, in our panel average statistic, these "large" values of individual Wald statistics are crushed by the others which converge in probability to zero. When $N$ tends to infinity, the cross-sectional average is likely to converge to zero. The null hypothesis of [the] homogeneous noncausality hypothesis will not be rejected." Our comments are given in squared parentheses.
} 
causality is rejected. Secondly, the asymptotic distribution of our statistics is established under the assumption of cross-section independence. As for panel unit root tests, it is now necessary to develop second generation panel non-causality tests that allow for general or specific cross-section dependencies. This is precisely our objective for future researches." Hurlin (2008, p. 20). Based on Hanck (2013) we present a procedure that addresses both of these drawbacks below.

\subsubsection{Testing GNC using Fisher's Method}

The Fisher panel test $(1932,1948)$, denoted $\lambda$,is:

$\lambda=-2 \sum_{i=1}^{N} \ln \left(p_{i}\right) \sim \chi^{2}(2 N)$

where, $p_{i}$ is the probability value for the $\mathrm{F}$ or Wald test for (in the current context) the GNC null for the $i^{\text {th }}$ cross-sectional unit and $l n$ denotes the natural logarithm operator. Fisher's test tests the null hypothesis of GNC for all $N$ cross-sections against the alternative that there is Granger-causality for at least one individual unit. If the $\lambda$ exceeds the critical value given by the $\chi^{2}$ distribution with $2 N$ degrees of freedom the null is rejected.

This test is subject to the same criticisms as Hurlin's (2008) method being that it does not account for any cross-sectional dependence and that when the null is rejected it does not indicate for how many or which cross-sectional units the null is rejected for.

\subsubsection{Testing GNC using Hanck's (2013) Method}

Hanck (2013) proposed an intersection panel unit root test, making use of Simes (1986) and Hommel's (1988) earlier work. The test is robust to general patterns of cross-sectional dependence, is straightforward to implement and can identify which cross-sectional units in the panel reject the null and which do not. ${ }^{13}$ However, we apply this intersection test within the context of GNC (rather than unit roots). We are not aware of this procedure being applied

\footnotetext{
${ }^{13}$ In being able to account for general forms of cross-sectional dependence Hanck (2008) argues that this has advantages over many second generation panel unit root tests where non-trivial decisions are required by the user in the implementation of the tests that may affect the outcome. Such decisions are not required in the application of the intersection unit root test. Hanck (2008, pp. $4-5)$ shows that the intersection test controls size for patterns of cross-sectional dependence often assumed in panel models with dynamics.
} 
within the context of GNC tests. This can be justified because the procedure is based on probability values from time-series tests and is not restricted to any specific class of tests ${ }^{14}$.

Within the GNC context the Simes-type panel test is based upon the estimated time-series equations for each cross-sectional unit as specified by (1). The HNC null hypothesis is reexpressed as follows:

$H_{0}=\bigcap_{i=1,2, \ldots, N} H_{i, 0}$

where, $\bigcap_{i=1,2, \ldots, N}$ denotes the intersection over the individual cross-sectional units for $i=1,2, \ldots, N$ and $H_{i 0}: \beta_{i}^{(1)}=\cdots=\beta_{i}^{\left(H_{i}\right)}=0$ for one particular $i$. If the null is rejected there is at least one cross-section that exhibits Granger-causality $(\mathrm{GC})$, that is:

$H_{1}=\bigcup_{i=1,2, \ldots, N} H_{i, 1}$

where, $\cup_{i=1,2, \ldots, N}$ denotes the union over the individual cross-sectional units for $i=1,2, \ldots$, $N \mathrm{r}$ and $H_{i, 1}: \beta_{i}^{(1)} \neq 0 \cup \ldots \cup \beta_{i}^{\left(H_{i}\right)} \neq 0$ for one particular $i$.

The test is based upon the probability values, $p_{i}$, of time-series $\mathrm{F}$ or Wald GNC tests for the null $H_{i, 0}$ obtained from the estimation of equation (1) for each of the $i$ cross-sectional units. These $N$ probability values are arranged in ascending order, thus, $p_{1} \leq p_{2} \leq \cdots \leq p_{N}$, where $p_{1}$ is associated with the cross-sectional unit that is most likely to reject $H_{i, 0}$.

The intersection test rejects the null for any individual cross-section in the panel at the $\alpha$ level of significance only if the following condition holds:

$p_{j} \leq \frac{j \alpha}{N} \quad$ for some $j=1,2, \ldots, N$

The $N$ ordered probability values are compared with ever increasing critical points, defined

\footnotetext{
${ }^{14}$ The procedure is appropriate for probability values based on test statistics that are multivariate totally positive of order two. This contains a large class of distributions including the absolute valued multivariate normal, absolute valued central multivariate $t$ and central multivariate F, see Hanck (2013). Given that GNC tests can be based on t, F and chi-squared distributions this would make this an appropriate test for use with Hanck's (2013) procedure.
} 
by $\frac{j \alpha}{N}$, and if at least one $p_{j}$ exceeds its critical point the null is rejected for the whole panel (hence, at least one cross-section exhibits GC) otherwise GNC is inferred for all individual units.

To identify which individual cross-sections in the panel reject, or fail to reject, the GNC null we follow Hanck (2013) in applying Hommel's (1988) procedure. The first step is to calculate $r$ such that the following condition holds (for all $q$ for a given $i$ ):

$r=\max \left\{p_{(N-i+q)}>\frac{q_{\alpha}}{i}\right\} \quad$ for $q=1,2, \ldots, i \quad$ where $\quad i=1,2, \ldots, N$

The second step is to use $r$ to determine which cross-sections reject the GNC null and which do not. In particular, if $r=0$ the GNC null is rejected for all cross- sectional units $-H_{i, 0}$ is rejected for all $i$. Whereas if $r>0$, reject the GNC null for all cross-sectional units where $p_{j} \leq \frac{\alpha}{r}$ and do not reject the null for all units where this condition is not satisfied. ${ }^{15}$

This panel GNC testing approach is referred to as the Simes-Hommel-Hanck (SHH) GNC intersection test. The ability of the SHH procedure to identify which countries exhibit GNC and which do not and to deal with cross-sectional dependence should make its inference superior to that obtained from the Hurlin and Fisher panel tests. The panel nature of the SHH procedure should make its influence superior to that of time-series tests, too.

\subsection{Data Description and Sources}

An unbalanced panel dataset of 136 countries (see column 1 of Table 2) covering the period 1970-2005 (annually) is used. The data were extracted from the WDI 2006 edition. The two variables employed are net inflows of FDI as a percentage of GDP (denoted FDIG), and real per-capita GDP growth (denoted GDPG). The unit of measurement for both variables (prior to transformation) is US dollars.

\footnotetext{
${ }^{15}$ In identifying which cross-sectional units in the panel reject the null and those which do not using a large number of tests Hommel (1998) proves that the above procedure controls for the "Familywise Error Rate" (FWER). That is, in choosing the level of significance for an individual test to be $\alpha$, the above procedure ensures that the size of the test for at least one unit's $H_{i, 0}$ is $\alpha$.
} 
Table 1: Time-series GNC tests

\begin{tabular}{|c|c|c|c|c|c|c|c|c|c|}
\hline \multirow[b]{2}{*}{ Country } & \multirow[b]{2}{*}{ Lags $(\mathbf{H})$} & \multicolumn{2}{|c|}{ GDPG to FDIG } & \multicolumn{2}{|c|}{ FDIG to GDPG } & \multicolumn{2}{|c|}{ GDPG to FDIG } & \multicolumn{2}{|c|}{ FDIG to GDPG } \\
\hline & & F-test & PF & F-test & PF & W & PW & w & PW \\
\hline Albania & 1 & 0.181 & 0.680 & 0.398 & 0.542 & 0.181 & 0.671 & 0.398 & 0.528 \\
\hline Algeria & 2 & 5.726 & 0.008 & 5.891 & 0.007 & 11.451 & 0.003 & 11.783 & 0.003 \\
\hline Angola & 1 & 0.517 & 0.482 & 0.642 & 0.434 & 0.517 & 0.472 & 0.642 & 0.423 \\
\hline Argentina & 1 & 1.327 & 0.260 & 0.098 & 0.757 & 1.327 & 0.249 & 0.098 & 0.754 \\
\hline Armenia & 1 & 0.095 & 0.764 & 0.000 & 0.993 & 0.095 & 0.758 & 0.000 & 0.993 \\
\hline Australia & 1 & 0.857 & 0.362 & 0.366 & 0.550 & 0.857 & 0.355 & 0.366 & 0.545 \\
\hline Austria & 1 & 0.029 & 0.865 & 0.870 & 0.358 & 0.029 & 0.864 & 0.870 & 0.351 \\
\hline Bangladesh & 3 & 5.984 & 0.041 & 0.675 & 0.604 & 17.953 & 0.000 & 2.025 & 0.567 \\
\hline Barbados & 1 & 0.016 & 0.901 & 4.333 & 0.053 & 0.016 & 0.899 & 4.333 & 0.037 \\
\hline Belarus & 1 & 0.035 & 0.853 & 0.222 & 0.641 & 0.035 & 0.851 & 0.222 & 0.637 \\
\hline Belgium & 1 & 3.638 & 0.086 & 0.024 & 0.881 & 3.638 & 0.057 & 0.024 & 0.878 \\
\hline Belize & 1 & 0.031 & 0.863 & 0.000 & 1.000 & 0.031 & 0.861 & 0.000 & 1.000 \\
\hline Benin & 1 & 0.576 & 0.457 & 0.205 & 0.656 & 0.576 & 0.448 & 0.205 & 0.651 \\
\hline Bolivia & 1 & 0.023 & 0.882 & 0.595 & 0.446 & 0.023 & 0.881 & 0.595 & 0.441 \\
\hline Botswana & 1 & 0.466 & 0.500 & 0.418 & 0.523 & 0.466 & 0.495 & 0.418 & 0.518 \\
\hline Brazil & 1 & 1.515 & 0.229 & 0.710 & 0.407 & 1.515 & 0.218 & 0.710 & 0.400 \\
\hline Bulgaria & 1 & 0.230 & 0.635 & 0.212 & 0.649 & 0.230 & 0.632 & 0.212 & 0.645 \\
\hline $\begin{array}{l}\text { Burkina } \\
\text { Faso }\end{array}$ & 3 & 0.154 & 0.924 & 5.137 & 0.043 & 0.461 & 0.927 & 15.410 & 0.002 \\
\hline Burundi & 1 & 1.848 & 0.184 & 0.939 & 0.340 & 1.848 & 0.174 & 0.939 & 0.333 \\
\hline Cambodia & 1 & 0.180 & 0.674 & 0.001 & 0.980 & 0.180 & 0.671 & 0.001 & 0.980 \\
\hline Canada & 1 & 3.268 & 0.081 & 0.972 & 0.332 & 3.268 & 0.071 & 0.972 & 0.324 \\
\hline $\begin{array}{l}\text { Central } \\
\text { Africa }\end{array}$ & 1 & 1.957 & 0.172 & 0.007 & 0.933 & 1.957 & 0.162 & 0.007 & 0.933 \\
\hline Chad & 1 & 3.009 & 0.092 & 0.710 & 0.406 & 3.009 & 0.083 & 0.710 & 0.400 \\
\hline Chile & 1 & 0.000 & 0.990 & 5.717 & 0.023 & 0.000 & 0.990 & 5.717 & 0.017 \\
\hline China & 1 & 1.617 & 0.213 & 0.373 & 0.546 & 1.617 & 0.204 & 0.373 & 0.541 \\
\hline Colombia & 1 & 2.182 & 0.153 & 0.199 & 0.660 & 2.182 & 0.140 & 0.199 & 0.656 \\
\hline Congo Dem & 1 & 0.184 & 0.671 & 2.215 & 0.146 & 0.184 & 0.668 & 2.215 & 0.137 \\
\hline Congo Rep & 1 & 0.714 & 0.404 & 0.200 & 0.658 & 0.714 & 0.398 & 0.200 & 0.655 \\
\hline Costa Rica & 1 & 0.185 & 0.670 & 0.790 & 0.381 & 0.185 & 0.667 & 0.790 & 0.374 \\
\hline Ivory Cost & 1 & 0.020 & 0.888 & 0.709 & 0.406 & 0.020 & 0.887 & 0.709 & 0.400 \\
\hline Croatia & 1 & 0.110 & 0.742 & 0.051 & 0.823 & 0.110 & 0.740 & 0.051 & 0.822 \\
\hline Cyprus & 1 & 0.358 & 0.564 & 1.530 & 0.247 & 0.358 & 0.550 & 1.530 & 0.216 \\
\hline Czech Rep & 1 & 0.009 & 0.926 & 1.068 & 0.311 & 0.009 & 0.925 & 1.068 & 0.302 \\
\hline Denmark & 1 & 0.038 & 0.850 & 0.531 & 0.483 & 0.038 & 0.846 & 0.531 & 0.466 \\
\hline Djibouti & 1 & 0.116 & 0.736 & 0.134 & 0.717 & 0.116 & 0.733 & 0.134 & 0.714 \\
\hline $\begin{array}{l}\text { Dominican } \\
\text { Rep }\end{array}$ & 2 & 2.321 & 0.169 & 0.371 & 0.703 & 4.642 & 0.098 & 0.742 & 0.690 \\
\hline Ecuador & 1 & 0.015 & 0.904 & 0.761 & 0.390 & 0.015 & 0.903 & 0.761 & 0.383 \\
\hline Egypt & 1 & 0.136 & 0.715 & 1.313 & 0.260 & 0.136 & 0.712 & 1.313 & 0.252 \\
\hline El Salvador & 1 & 1.547 & 0.223 & 5.760 & 0.023 & 1.547 & 0.214 & 5.760 & 0.016 \\
\hline Equatorial & 1 & 0.252 & 0.619 & 0.001 & 0.977 & 0.252 & 0.616 & 0.001 & 0.977 \\
\hline
\end{tabular}


Table 1: Time-series GNC tests (continued)

\begin{tabular}{|c|c|c|c|c|c|c|c|c|c|}
\hline \multirow[b]{2}{*}{ Country } & \multirow[b]{2}{*}{ Lags $(\mathbf{H})$} & \multicolumn{2}{|c|}{ GDPG to FDIG } & \multicolumn{2}{|c|}{ FDIG to GDPG } & \multicolumn{2}{|c|}{ GDPG to FDIG } & \multicolumn{2}{|c|}{ FDIG to GDPG } \\
\hline & & F-test & PF & F-test & PF & w & PW & W & PW \\
\hline Estonia & 1 & 0.521 & 0.482 & 66.424 & 0.000 & 0.521 & 0.471 & 66.424 & 0.000 \\
\hline Ethiopia & 1 & 0.987 & 0.344 & 0.441 & 0.522 & 0.987 & 0.321 & 0.441 & 0.507 \\
\hline Fiji & 1 & 0.317 & 0.580 & 0.436 & 0.517 & 0.317 & 0.573 & 0.436 & 0.509 \\
\hline Finland & 1 & 0.161 & 0.692 & 3.619 & 0.067 & 0.161 & 0.689 & 3.619 & 0.057 \\
\hline France & 2 & 0.485 & 0.622 & 1.245 & 0.306 & 0.969 & 0.616 & 2.489 & 0.288 \\
\hline Gabon & 1 & 5.370 & 0.028 & 1.865 & 0.183 & 5.370 & 0.021 & 1.865 & 0.172 \\
\hline Germany & 1 & 0.144 & 0.707 & 1.343 & 0.255 & 0.144 & 0.705 & 1.343 & 0.247 \\
\hline Ghana & 1 & 0.078 & 0.782 & 0.583 & 0.451 & 0.078 & 0.780 & 0.583 & 0.445 \\
\hline Greece & 1 & 4.205 & 0.049 & 0.159 & 0.693 & 4.205 & 0.040 & 0.159 & 0.690 \\
\hline Grenada & 1 & 0.686 & 0.416 & 1.511 & 0.231 & 0.686 & 0.407 & 1.511 & 0.219 \\
\hline Guatemala & 1 & 0.016 & 0.900 & 0.746 & 0.397 & 0.016 & 0.899 & 0.746 & 0.388 \\
\hline Guinea & 1 & 0.182 & 0.673 & 1.994 & 0.168 & 0.182 & 0.670 & 1.994 & 0.158 \\
\hline $\begin{array}{l}\text { Guinea } \\
\text { Bissau }\end{array}$ & 1 & 0.182 & 0.676 & 5.359 & 0.035 & 0.182 & 0.670 & 5.359 & 0.021 \\
\hline Guyana & 1 & 1.447 & 0.245 & 20.201 & 0.000 & 1.447 & 0.229 & 20.201 & 0.000 \\
\hline Haiti & 1 & 2.120 & 0.155 & 3.450 & 0.073 & 2.120 & 0.145 & 3.450 & 0.063 \\
\hline Honduras & 1 & 0.666 & 0.421 & 11.874 & 0.002 & 0.666 & 0.415 & 11.874 & 0.001 \\
\hline Hungary & 1 & 0.665 & 0.421 & 0.014 & 0.907 & 0.665 & 0.415 & 0.014 & 0.906 \\
\hline Iceland & 1 & 0.115 & 0.739 & 1.790 & 0.199 & 0.115 & 0.734 & 1.790 & 0.181 \\
\hline India & 1 & 0.675 & 0.419 & 0.060 & 0.809 & 0.675 & 0.411 & 0.060 & 0.807 \\
\hline Indonesia & 1 & 1.600 & 0.215 & 3.198 & 0.083 & 1.600 & 0.206 & 3.198 & 0.074 \\
\hline Iran & 1 & 5.656 & 0.024 & 0.053 & 0.820 & 5.656 & 0.017 & 0.053 & 0.819 \\
\hline Ireland & 1 & 6.465 & 0.017 & 0.955 & 0.337 & 6.465 & 0.011 & 0.955 & 0.329 \\
\hline Israel & 1 & 4.234 & 0.049 & 0.000 & 0.984 & 4.234 & 0.040 & 0.000 & 0.984 \\
\hline Italy & 1 & 0.012 & 0.914 & 1.462 & 0.235 & 0.012 & 0.914 & 1.462 & 0.227 \\
\hline Jamaica & 1 & 0.127 & 0.724 & 1.407 & 0.244 & 0.127 & 0.721 & 1.407 & 0.236 \\
\hline Japan & 1 & 0.800 & 0.378 & 2.961 & 0.095 & 0.800 & 0.371 & 2.961 & 0.085 \\
\hline Jordan & 1 & 4.970 & 0.035 & 0.046 & 0.832 & 4.970 & 0.026 & 0.046 & 0.830 \\
\hline Kazakhstan & 1 & 0.022 & 0.883 & 0.002 & 0.966 & 0.022 & 0.882 & 0.002 & 0.966 \\
\hline Kenya & 1 & 4.559 & 0.059 & 0.420 & 0.532 & 4.559 & 0.033 & 0.420 & 0.517 \\
\hline Korea & 1 & 0.444 & 0.510 & 4.931 & 0.034 & 0.444 & 0.505 & 4.931 & 0.026 \\
\hline Kuwait & 1 & 6.324 & 0.018 & 0.024 & 0.879 & 6.324 & 0.012 & 0.024 & 0.878 \\
\hline Kyrgyz Rep & 1 & 0.046 & 0.832 & 0.020 & 0.888 & 0.046 & 0.830 & 0.020 & 0.887 \\
\hline Lesotho & 1 & 0.015 & 0.903 & 2.727 & 0.123 & 0.015 & 0.901 & 2.727 & 0.099 \\
\hline Liberia & 1 & 0.024 & 0.877 & 0.024 & 0.878 & 0.024 & 0.876 & 0.024 & 0.877 \\
\hline Lithuania & 1 & 1.922 & 0.175 & 6.507 & 0.016 & 1.922 & 0.166 & 6.507 & 0.011 \\
\hline Macedonia & 1 & 4.066 & 0.071 & 1.566 & 0.239 & 4.066 & 0.044 & 1.566 & 0.211 \\
\hline Madagascar & 2 & 1.889 & 0.213 & 0.511 & 0.619 & 3.777 & 0.151 & 1.021 & 0.600 \\
\hline Malawi & 1 & 0.506 & 0.482 & 0.524 & 0.474 & 0.506 & 0.477 & 0.524 & 0.469 \\
\hline Malaysia & 1 & 0.508 & 0.482 & 4.256 & 0.049 & 0.508 & 0.476 & 4.256 & 0.039 \\
\hline Mali & 1 & 0.153 & 0.698 & 0.009 & 0.924 & 0.153 & 0.696 & 0.009 & 0.924 \\
\hline Mauritania & 1 & 0.501 & 0.484 & 1.714 & 0.200 & 0.501 & 0.479 & 1.714 & 0.190 \\
\hline
\end{tabular}


Table 1: Time-series GNC tests (continued)

\begin{tabular}{|c|c|c|c|c|c|c|c|c|c|}
\hline \multirow[b]{2}{*}{ Country } & \multirow[b]{2}{*}{ Lags $(\mathbf{H})$} & \multicolumn{2}{|c|}{ GDPG to FDIG } & \multicolumn{2}{|c|}{ FDIG to GDPG } & \multicolumn{2}{|c|}{ GDPG to FDIG } & \multicolumn{2}{|c|}{ FDIG to GDPG } \\
\hline & & F-test & PF & F-test & PF & W & PW & W & PW \\
\hline Mauritius & 2 & 0.926 & 0.414 & 4.441 & 0.027 & 1.852 & 0.396 & 8.882 & 0.012 \\
\hline Mexico & 1 & 2.737 & 0.108 & 1.069 & 0.309 & 2.737 & 0.098 & 1.069 & 0.301 \\
\hline Moldova & 1 & 1.423 & 0.260 & 2.285 & 0.162 & 1.423 & 0.233 & 2.285 & 0.131 \\
\hline Mongolia & 3 & 1.430 & 0.338 & 0.193 & 0.897 & 4.291 & 0.232 & 0.578 & 0.901 \\
\hline Morocco & 1 & 0.744 & 0.395 & 0.798 & 0.378 & 0.744 & 0.388 & 0.798 & 0.372 \\
\hline Mozambic & 1 & 1.456 & 0.241 & 0.552 & 0.466 & 1.456 & 0.228 & 0.552 & 0.457 \\
\hline Nepal & 1 & 0.002 & 0.968 & 0.002 & 0.962 & 0.002 & 0.968 & 0.002 & 0.961 \\
\hline Netherlands & 1 & 2.684 & 0.111 & 1.099 & 0.302 & 2.684 & 0.101 & 1.099 & 0.294 \\
\hline $\begin{array}{l}\text { New } \\
\text { Zealand }\end{array}$ & 1 & 0.385 & 0.540 & 0.094 & 0.761 & 0.385 & 0.535 & 0.094 & 0.759 \\
\hline Nicaragua & 1 & 0.088 & 0.770 & 1.672 & 0.207 & 0.088 & 0.767 & 1.672 & 0.196 \\
\hline Niger & 1 & 6.578 & 0.015 & 0.178 & 0.676 & 6.578 & 0.010 & 0.178 & 0.673 \\
\hline Nigeria & 1 & 0.718 & 0.404 & 2.363 & 0.136 & 0.718 & 0.397 & 2.363 & 0.124 \\
\hline Norway & 2 & 3.543 & 0.045 & 0.887 & 0.425 & 7.087 & 0.029 & 1.773 & 0.412 \\
\hline Oman & 1 & 9.628 & 0.004 & 0.438 & 0.513 & 9.628 & 0.002 & 0.438 & 0.508 \\
\hline Pakistan & 1 & 0.002 & 0.966 & 0.797 & 0.379 & 0.002 & 0.966 & 0.797 & 0.372 \\
\hline Panama & 1 & 0.005 & 0.944 & 0.793 & 0.380 & 0.005 & 0.944 & 0.793 & 0.373 \\
\hline Paraguay & 1 & 0.161 & 0.691 & 0.403 & 0.530 & 0.161 & 0.689 & 0.403 & 0.525 \\
\hline Peru & 1 & 0.236 & 0.630 & 0.868 & 0.359 & 0.236 & 0.627 & 0.868 & 0.352 \\
\hline Philipines & 1 & 0.003 & 0.958 & 0.030 & 0.863 & 0.003 & 0.958 & 0.030 & 0.862 \\
\hline Poland & 1 & 2.415 & 0.148 & 15.103 & 0.003 & 2.415 & 0.120 & 15.103 & 0.000 \\
\hline Portugal & 1 & 1.118 & 0.300 & 1.331 & 0.259 & 1.118 & 0.290 & 1.331 & 0.249 \\
\hline Romania & 1 & 0.899 & 0.362 & 0.135 & 0.720 & 0.899 & 0.343 & 0.135 & 0.714 \\
\hline Rwanda & 1 & 0.193 & 0.663 & 0.035 & 0.852 & 0.193 & 0.660 & 0.035 & 0.851 \\
\hline Senegal & 1 & 0.046 & 0.831 & 1.241 & 0.274 & 0.046 & 0.830 & 1.241 & 0.265 \\
\hline Siera Leon & 1 & 0.733 & 0.398 & 0.114 & 0.738 & 0.733 & 0.392 & 0.114 & 0.736 \\
\hline Singapore & 1 & 0.082 & 0.777 & 1.207 & 0.281 & 0.082 & 0.775 & 1.207 & 0.272 \\
\hline Slovak Rep & 3 & 0.178 & 0.907 & 0.850 & 0.515 & 0.534 & 0.911 & 2.550 & 0.466 \\
\hline Slovania & 1 & 0.020 & 0.891 & 2.520 & 0.144 & 0.020 & 0.888 & 2.520 & 0.112 \\
\hline Somalia & 1 & 0.002 & 0.967 & 0.227 & 0.640 & 0.002 & 0.967 & 0.227 & 0.634 \\
\hline South Africa & 1 & 2.254 & 0.143 & 0.036 & 0.851 & 2.254 & 0.133 & 0.036 & 0.850 \\
\hline Spain & 1 & 5.082 & 0.033 & 0.046 & 0.831 & 5.082 & 0.024 & 0.046 & 0.830 \\
\hline Sri Lanka & 1 & 0.006 & 0.941 & 0.620 & 0.437 & 0.006 & 0.941 & 0.620 & 0.431 \\
\hline Sudan & 1 & 0.200 & 0.658 & 0.262 & 0.613 & 0.200 & 0.655 & 0.262 & 0.609 \\
\hline Swaziland & 1 & 0.453 & 0.506 & 0.200 & 0.658 & 0.453 & 0.501 & 0.200 & 0.655 \\
\hline Sweden & 1 & 0.158 & 0.693 & 1.028 & 0.318 & 0.158 & 0.691 & 1.028 & 0.311 \\
\hline Switzerland & 1 & 0.222 & 0.643 & 0.509 & 0.484 & 0.222 & 0.637 & 0.509 & 0.476 \\
\hline Syrian & 1 & 0.204 & 0.655 & 1.119 & 0.299 & 0.204 & 0.651 & 1.119 & 0.290 \\
\hline Tajikistan & 1 & 2.100 & 0.178 & 0.030 & 0.866 & 2.100 & 0.147 & 0.030 & 0.862 \\
\hline Tanzania & 1 & 0.165 & 0.692 & 6.215 & 0.027 & 0.165 & 0.685 & 6.215 & 0.013 \\
\hline Thailand & 1 & 0.745 & 0.395 & 0.303 & 0.586 & 0.745 & 0.388 & 0.303 & 0.582 \\
\hline Togo & 1 & 0.151 & 0.701 & 1.311 & 0.261 & 0.151 & 0.698 & 1.311 & 0.252 \\
\hline
\end{tabular}


Table 1: Time-series GNC tests (continued)

\begin{tabular}{|c|c|c|c|c|c|c|c|c|c|}
\hline \multirow[b]{2}{*}{ Country } & \multirow[b]{2}{*}{ Lags (H) } & \multicolumn{2}{|c|}{ GDPG to FDIG } & \multicolumn{2}{|c|}{ FDIG to GDPG } & \multicolumn{2}{|c|}{ GDPG to FDIG } & \multicolumn{2}{|c|}{ FDIG to GDPG } \\
\hline & & F-test & PF & F-test & PF & W & PW & W & PW \\
\hline Tonga & 1 & 0.023 & 0.882 & 0.003 & 0.954 & 0.023 & 0.880 & 0.003 & 0.953 \\
\hline Tunisia & 1 & 3.396 & 0.075 & 2.301 & 0.139 & 3.396 & 0.065 & 2.301 & 0.129 \\
\hline Turkey & 1 & 5.364 & 0.027 & 0.962 & 0.334 & 5.364 & 0.021 & 0.962 & 0.327 \\
\hline Uganda & 1 & 0.277 & 0.607 & 0.047 & 0.832 & 0.277 & 0.599 & 0.047 & 0.828 \\
\hline UK & 1 & 2.519 & 0.122 & 0.694 & 0.411 & 2.519 & 0.113 & 0.694 & 0.405 \\
\hline USA & 1 & 1.714 & 0.200 & 1.149 & 0.292 & 1.714 & 0.191 & 1.149 & 0.284 \\
\hline Uruguay & 1 & 0.270 & 0.607 & 1.299 & 0.263 & 0.270 & 0.603 & 1.299 & 0.254 \\
\hline Uzbekistan & 2 & 1.566 & 0.274 & 2.016 & 0.203 & 3.132 & 0.209 & 4.033 & 0.133 \\
\hline Vanuatu & 1 & 1.945 & 0.177 & 0.094 & 0.763 & 1.945 & 0.163 & 0.094 & 0.760 \\
\hline Venezuela & 1 & 0.124 & 0.727 & 0.058 & 0.811 & 0.124 & 0.725 & 0.058 & 0.809 \\
\hline Vietnam & 1 & 5.047 & 0.038 & 0.438 & 0.517 & 5.047 & 0.025 & 0.438 & 0.508 \\
\hline Yemen & 1 & 0.316 & 0.586 & 0.549 & 0.474 & 0.316 & 0.574 & 0.549 & 0.459 \\
\hline Zambia & 1 & 0.325 & 0.573 & 0.415 & 0.524 & 0.325 & 0.569 & 0.415 & 0.520 \\
\hline Zimbabwe & 1 & 0.082 & 0.777 & 0.900 & 0.350 & 0.082 & 0.775 & 0.900 & 0.343 \\
\hline Hurlin & & & & & & 1.369 & 0.086 & 4.502 & 0.000 \\
\hline Fisher & & 303.867 & 0.089 & 348.541 & 0.001 & 335.918 & 0.005 & 432.065 & 0.000 \\
\hline
\end{tabular}

Table 1 notes:

PF and PW denote probability values for the F and Wald (W) time-series GNC test statistics, respectively. Lags (H) denote the lag length used in the VAR. Hurlin denotes Hurlin's panel GNC Wald test allowing for heterogeneous $\mathrm{T}$ and $\mathrm{H}$ (which is appropriate for finite $\mathrm{T}$ and large $\mathrm{N}$ ) and the corresponding (one-tail) asymptotic (normal) p-values beneath PW. Asymptotic (one-tail normal distribution) 1\%, 5\% and 10\% critical values for Hurlin's test are, respectively: $2.326,1.645$ and 1.282 . Semi-asymptotic (one-tail) $1 \%, 5 \%$ and $10 \%$ critical values for Hurlin's test are, respectively: 1.664, 1.550 and 1.489. Fisher denotes Fisher's panel GNC tests (both and $\mathrm{F}$ and Wald versions below their associated headings) with corresponding chi-squared (with $2 \mathrm{~N}$ degrees of freedom) probability values beneath PF and PW. The 1\%, 5\% and 10\% critical values for the Fishertype panel GNC test are: $329.181,311.467$ and 302.286.

\section{Empirical Results}

We test the GNC null in bivariate VARs for both FDIG to GDPG and the reverse causality relationship of GDPG to FDIG. The three panel tests discussed above are applied as well as standard time-series tests. Results based on both Wald and F statistics are given. The timeseries, Hurlin and Fisher tests are presented in Table 1 while Table 2 and Table 3 report the results of the SHH method. 


\subsection{Time-series results}

The lag lengths of the VAR chosen for both variables in each country according to Schwarz's Information criteria (SIC), with a maximum of 3 lags, are given in column 2 of Table 1 (when the SIC favoured zero lags GNC tests were applied in a VAR with 1 lag). Columns 3 and 6 (7 to 10) report statistics relating to F (Wald) versions of the GNC tests (where PF and PW denote the probability values of $\mathrm{F}$ and Wald statistics, respectively). Columns 3, 4, 7 and 8 give test statistics for GDPG causing FDIG (denoted GDPG to FDIG) whereas columns 5, 6, 9 and 10 report test statistics for FDIG causing GDPG (denoted FDIG to GDPG).

According to the F-test there is evidence of GC from GDPG to FDIG at the 5\% level for 15 of the 136 countries (Algeria, Bangladesh, Gabon, Greece, Iran, Ireland, Israel, Jordan, Kuwait, Niger, Norway, Oman, Spain, Turkey and Vietnam). ${ }^{16}$ Similarly, the Wald test suggests that there is evidence of GC from GDPG to FDIG at the 5\% level for 17 countries (the same 15 countries as identified by the F-test plus Kenya and Macedonia). ${ }^{17}$ The F-test indicates evidence of GC from FDIG to GDPG at the 5\% level for 14 countries (Algeria, Burkina Faso, Chile, El Salvador, Estonia, Guinea Bissau, Guyana, Honduras, South Korea, Lithuania, Malaysia, Mauritius, Poland and Tanzania). ${ }^{18}$ The Wald test identifies evidence of GC from FDIG to GDPG at the 5\% level for 15 countries (the same 14 countries indicated by the F-test plus Barbados). ${ }^{19}$ Where there is evidence of GC it is unidirectional except for Algeria where bidirectional causality is suggested. Whilst there is evidence of GC for a small number of countries, the time-series results indicate no causality in either direction for the vast majority of countries- 108 or $79.4 \%$ according to the F-test and 105 or $77.2 \%$ using the Wald test.

\subsection{Fisher and Hurlin panel results}

The rows labelled Hurlin and Fisher at the bottom of the Table 1 give the Hurlin and Fisher panel test statistics with associated probability values. The probability values for Fisher statistics based on the F (Wald) version of the GNC test are 0.089 (0.005) for GDPG to FDI and $0.001(0.000)$ for FDIG to GDPG. The test results cause us to reject the GNC null

\footnotetext{
${ }^{16}$ Using a $1 \%(10 \%)$ level there is evidence of GC from GDPG to FDIG for 2 (26) countries.

${ }^{17}$ Using a $1 \%(10 \%)$ level there is evidence of GC from GDPG to FDIG for 3 (23) countries.

${ }^{18}$ Using a $1 \%(10 \%)$ level there is evidence of GC from FDIG to GDPG for 5 (19) countries.

${ }^{19}$ Using a $1 \%(10 \%)$ level there is evidence of GC from FDIG to GDPG for 5 (19) countries.
} 
hypothesis for all countries at the 5\% level of significance for all tests except that based on the F-version for GDPG causing FDIG, where the null can only be rejected at the $10 \%$ level. These results unambiguously suggest that FDIG Granger-causes GDPG for at least one country. While the evidence is ambiguous as to whether GDPG Granger-causes FDIG for at least one country this (alternative) hypothesis is not convincingly rejected and we cannot discount the probability that GC exists in this direction as well for at least one country.

The one tailed probability values based on the Normal distribution for Hurlin's (2004a,b) panel test, presented at the bottom of Table 2, are only available for the Wald version of the test, see equation (4). The probability value for Granger-causality from GDPG to FDIG is 0.086 which suggests that GDPG does not Granger-cause FDIG at the 5\% level for any of the 136 countries in the panel - if it is rejected at the $10 \%$ level. In contrast, the probability for GNC from FDIG to GDPG is 0.000 which rejects the null hypothesis at all conventional levels of significance and unambiguously indicates that FDI Granger-causes GDPG for at least one country in the panel.

Hence, the Fisher and Hurlin panel tests unambiguously indicate that FDI Granger-causes GDPG for at least one country, however, they both show some ambiguity as to whether GDPG Granger-causes FDI.

\subsection{Panel SHH results}

This section considers the GNC test results from the SHH panel method based upon probability values from the time-series F-tests and Wald tests. These are reported in Table 2 and Table 3 , respectively. 
Table 2: SHH GNC test (F-statistic)

\begin{tabular}{|c|c|c|c|c|c|c|c|}
\hline \multicolumn{4}{|c|}{ GDPG to FDIG } & \multicolumn{4}{|c|}{ FDIG to GDPG } \\
\hline Country & $P_{j}$ & $\frac{\alpha}{r}$ & Decision & Country & $\mathrm{P}_{\mathrm{j}}$ & $\frac{\alpha}{r}$ & Decision \\
\hline Oman & 0.00407 & 0.00037 & Accept & Estonia & 0.00000 & 0.00037 & Reject \\
\hline Algeria & 0.00802 & 0.00037 & Accept & Guyana & 0.00028 & 0.00037 & Reject \\
\hline Niger & 0.01522 & 0.00037 & Accept & Honduras & 0.00161 & 0.00037 & Accept \\
\hline Ireland & 0.01660 & 0.00037 & Accept & Poland & 0.00254 & 0.00037 & Accept \\
\hline Kuwait & 0.01843 & 0.00037 & Accept & Algeria & 0.00713 & 0.00037 & Accept \\
\hline Iran & 0.02353 & 0.00037 & Accept & Lithuania & 0.01573 & 0.00037 & Accept \\
\hline Turkey & 0.02712 & 0.00037 & Accept & El Salvador & 0.02281 & 0.00037 & Accept \\
\hline Gabon & 0.02831 & 0.00037 & Accept & Chile & 0.02285 & 0.00037 & Accept \\
\hline Spain & 0.03250 & 0.00037 & Accept & Tanzania & 0.02694 & 0.00037 & Accept \\
\hline Jordan & 0.03501 & 0.00037 & Accept & Mauritius & 0.02706 & 0.00037 & Accept \\
\hline Vietnam & 0.03824 & 0.00037 & Accept & Korea & 0.03358 & 0.00037 & Accept \\
\hline Bangladesh & 0.04144 & 0.00037 & Accept & Guinea Bissau & 0.03519 & 0.00037 & Accept \\
\hline Norway & 0.04484 & 0.00037 & Accept & Burkina Faso & 0.04276 & 0.00037 & Accept \\
\hline Greece & 0.04857 & 0.00037 & Accept & Malaysia & 0.04850 & 0.00037 & Accept \\
\hline Israel & 0.04904 & 0.00037 & Accept & Barbados & 0.05280 & 0.00037 & Accept \\
\hline Kenya & 0.05850 & 0.00037 & Accept & Finland & 0.06744 & 0.00037 & Accept \\
\hline Macedonia & 0.07140 & 0.00037 & Accept & Haiti & 0.07249 & 0.00037 & Accept \\
\hline Tunisia & 0.07464 & 0.00037 & Accept & Indonesia & 0.08319 & 0.00037 & Accept \\
\hline Canada & 0.08068 & 0.00037 & Accept & Japan & 0.09495 & 0.00037 & Accept \\
\hline Belgium & 0.08558 & 0.00037 & Accept & Lesotho & 0.12259 & 0.00037 & Accept \\
\hline Chad & 0.09241 & 0.00037 & Accept & Nigeria & 0.13545 & 0.00037 & Accept \\
\hline Mexico & 0.10784 & 0.00037 & Accept & Tunisia & 0.13915 & 0.00037 & Accept \\
\hline Netherland & 0.11117 & 0.00037 & Accept & Slovenia & 0.14347 & 0.00037 & Accept \\
\hline UK & 0.12233 & 0.00037 & Accept & Congo Dem & 0.14643 & 0.00037 & Accept \\
\hline South Africa & 0.14309 & 0.00037 & Accept & Moldova & 0.16158 & 0.00037 & Accept \\
\hline Poland & 0.14844 & 0.00037 & Accept & Guinea & 0.16759 & 0.00037 & Accept \\
\hline Colombia & 0.15317 & 0.00037 & Accept & Gabon & 0.18329 & 0.00037 & Accept \\
\hline Haiti & 0.15513 & 0.00037 & Accept & Iceland & 0.19860 & 0.00037 & Accept \\
\hline Dominican Rep & 0.16857 & 0.00037 & Accept & Mauritania & 0.20005 & 0.00037 & Accept \\
\hline Central Africa & 0.17150 & 0.00037 & Accept & Uzbekistan & 0.20344 & 0.00037 & Accept \\
\hline Lithuania & 0.17522 & 0.00037 & Accept & Nicaragua & 0.20662 & 0.00037 & Accept \\
\hline Vanuatu & 0.17710 & 0.00037 & Accept & Grenada & 0.23086 & 0.00037 & Accept \\
\hline Tajikistan & 0.17788 & 0.00037 & Accept & Italy & 0.23539 & 0.00037 & Accept \\
\hline Burundi & 0.18354 & 0.00037 & Accept & Macedonia & 0.23926 & 0.00037 & Accept \\
\hline USA & 0.19981 & 0.00037 & Accept & Jamaica & 0.24437 & 0.00037 & Accept \\
\hline China & 0.21266 & 0.00037 & Accept & Cyprus & 0.24742 & 0.00037 & Accept \\
\hline Madagascar & 0.21290 & 0.00037 & Accept & Germany & 0.25516 & 0.00037 & Accept \\
\hline Indonesia & 0.21506 & 0.00037 & Accept & Portugal & 0.25871 & 0.00037 & Accept \\
\hline El Salvador & 0.22315 & 0.00037 & Accept & Egypt & 0.26035 & 0.00037 & Accept \\
\hline Brazil & 0.22858 & 0.00037 & Accept & Togo & 0.26067 & 0.00037 & Accept \\
\hline Mozambique & 0.24091 & 0.00037 & Accept & Uruguay & 0.26287 & 0.00037 & Accept \\
\hline Guyana & 0.24464 & 0.00037 & Accept & Senegal & 0.27362 & 0.00037 & Accept \\
\hline Argentina & 0.26016 & 0.00037 & Accept & Singapore & 0.28075 & 0.00037 & Accept \\
\hline Moldova & 0.26038 & 0.00037 & Accept & USA & 0.29176 & 0.00037 & Accept \\
\hline Uzbekistan & 0.27409 & 0.00037 & Accept & Syrian & 0.29852 & 0.00037 & Accept \\
\hline Portugal & 0.29978 & 0.00037 & Accept & Netherland & 0.30226 & 0.00037 & Accept \\
\hline Mongolia & 0.33817 & 0.00037 & Accept & France & 0.30602 & 0.00037 & Accept \\
\hline
\end{tabular}


Table 2: SHH GNC test (F-statistic) continued

\begin{tabular}{|c|c|c|c|c|c|c|c|}
\hline \multicolumn{4}{|c|}{ GDPG to FDIG } & \multicolumn{4}{|c|}{ FDIG to GDPG } \\
\hline Country & $P_{j}$ & $\frac{\alpha}{r}$ & Decision & Country & $\mathrm{P}_{\mathrm{j}}$ & $\frac{\alpha}{r}$ & sion \\
\hline Ethiopia & 0.34389 & 0.00037 & Accept & Mexico & 0.30893 & 0.00037 & Accept \\
\hline Australia & 0.36163 & 0.00037 & Accept & Czech Rep & 0.31139 & 0.00037 & Accept \\
\hline Romania & 0.36166 & 0.00037 & Accept & Sweden & 0.31832 & 0.00037 & Accept \\
\hline Japan & 0.37770 & 0.00037 & Accept & Canada & 0.33207 & 0.00037 & Accept \\
\hline Thailand & 0.39462 & 0.00037 & Accept & Turkey & 0.33396 & 0.00037 & Accept \\
\hline Morocco & 0.39467 & 0.00037 & Accept & Ireland & 0.33662 & 0.00037 & Accept \\
\hline Sierra leon & 0.39829 & 0.00037 & Accept & Burundi & 0.33992 & 0.00037 & Accept \\
\hline Nigeria & 0.40402 & 0.00037 & Accept & Zimbabwe & 0.34977 & 0.00037 & Accept \\
\hline Congo Dem & 0.40428 & 0.00037 & Accept & Austria & 0.35797 & 0.00037 & Accept \\
\hline Mauritius & 0.41412 & 0.00037 & Accept & Peru & 0.35853 & 0.00037 & Accept \\
\hline Grenada & 0.41555 & 0.00037 & Accept & Morocco & 0.37840 & 0.00037 & Accept \\
\hline India & 0.41885 & 0.00037 & Accept & Pakistan & 0.37870 & 0.00037 & Accept \\
\hline Honduras & 0.42053 & 0.00037 & Accept & Panama & 0.37991 & 0.00037 & Accept \\
\hline Hungary & 0.42097 & 0.00037 & Accept & Costa Rica & 0.38082 & 0.00037 & Accept \\
\hline Benin & 0.45678 & 0.00037 & Accept & Ecuador & 0.38961 & 0.00037 & Accept \\
\hline Estonia & 0.48167 & 0.00037 & Accept & Guatemala & 0.39679 & 0.00037 & Accept \\
\hline Malaysia & 0.48170 & 0.00037 & Accept & Chad & 0.40585 & 0.00037 & Accept \\
\hline Angola & 0.48204 & 0.00037 & Accept & Ivory cost & 0.40617 & 0.00037 & Accept \\
\hline Malawi & 0.48223 & 0.00037 & Accept & Brazil & 0.40674 & 0.00037 & Accept \\
\hline Mauritania & 0.48418 & 0.00037 & Accept & UK & 0.41084 & 0.00037 & Accept \\
\hline Botswana & 0.49965 & 0.00037 & Accept & Norway & 0.42515 & 0.00037 & Accept \\
\hline Swaziland & 0.50615 & 0.00037 & Accept & Angola & 0.43401 & 0.00037 & Accept \\
\hline Korea & 0.51001 & 0.00037 & Accept & Sri Lanka & 0.43696 & 0.00037 & Accept \\
\hline New Zealand & 0.53996 & 0.00037 & Accept & Bolivia & 0.44615 & 0.00037 & Accept \\
\hline Cyprus & 0.56445 & 0.00037 & Accept & Ghana & 0.45092 & 0.00037 & Accept \\
\hline Zambia & 0.57261 & 0.00037 & Accept & Mozambique & 0.46557 & 0.00037 & Accept \\
\hline Fiji & 0.57957 & 0.00037 & Accept & Yemen & 0.47407 & 0.00037 & Accept \\
\hline Yemen & 0.58545 & 0.00037 & Accept & Malawi & 0.47421 & 0.00037 & Accept \\
\hline Uruguay & 0.60697 & 0.00037 & Accept & Denmark & 0.48289 & 0.00037 & Accept \\
\hline Uganda & 0.60700 & 0.00037 & Accept & Switzerland & 0.48440 & 0.00037 & Accept \\
\hline Equatorial & 0.61902 & 0.00037 & Accept & Oman & 0.51308 & 0.00037 & Accept \\
\hline France & 0.62188 & 0.00037 & Accept & Slovak Rep & 0.51523 & 0.00037 & Accept \\
\hline Peru & 0.63007 & 0.00037 & Accept & Fiji & 0.51651 & 0.00037 & Accept \\
\hline Bulgaria & 0.63497 & 0.00037 & Accept & Vietnam & 0.51695 & 0.00037 & Accept \\
\hline Switzerland & 0.64267 & 0.00037 & Accept & Ethiopia & 0.52185 & 0.00037 & Accept \\
\hline Syrian & 0.65463 & 0.00037 & Accept & Botswana & 0.52256 & 0.00037 & Accept \\
\hline Sudan & 0.65807 & 0.00037 & Accept & Zambia & 0.52422 & 0.00037 & Accept \\
\hline Rwanda & 0.66332 & 0.00037 & Accept & Paraguay & 0.52994 & 0.00037 & Accept \\
\hline Costa Rica & 0.66981 & 0.00037 & Accept & Kenya & 0.53162 & 0.00037 & Accept \\
\hline Congo Rep & 0.67120 & 0.00037 & Accept & Albania & 0.54220 & 0.00037 & Accept \\
\hline Guinea & 0.67264 & 0.00037 & Accept & China & 0.54548 & 0.00037 & Accept \\
\hline Cambodia & 0.67401 & 0.00037 & Accept & Australia & 0.54954 & 0.00037 & Accept \\
\hline Guinea Bissau & 0.67554 & 0.00037 & Accept & Thailand & 0.58584 & 0.00037 & Accept \\
\hline Albania & 0.67974 & 0.00037 & Accept & Bangladesh & 0.60362 & 0.00037 & Accept \\
\hline Paraguay & 0.69126 & 0.00037 & Accept & Sudan & 0.61283 & 0.00037 & Accept \\
\hline Tanzania & 0.69150 & 0.00037 & Accept & Madagascar & 0.61849 & 0.00037 & Accept \\
\hline Finland & 0.69169 & 0.00037 & Accept & Somalia & 0.63957 & 0.00037 & Accept \\
\hline
\end{tabular}


Table 2: SHH GNC test (F-statistic) continued

\begin{tabular}{|c|c|c|c|c|c|c|c|}
\hline \multicolumn{4}{|c|}{ GDPG to FDIG } & \multicolumn{4}{|c|}{ FDIG to GDPG } \\
\hline Country & $P_{j}$ & $\frac{\alpha}{r}$ & Decision & Country & $P_{j}$ & $\frac{\alpha}{r}$ & Decision \\
\hline Sweden & 0.69342 & 0.00037 & Accept & Belarus & 0.64134 & 0.00037 & Accept \\
\hline Mali & 0.69820 & 0.00037 & Accept & Bulgaria & 0.64851 & 0.00037 & Accept \\
\hline Togo & 0.70062 & 0.00037 & Accept & Benin & 0.65577 & 0.00037 & Accept \\
\hline Germany & 0.70707 & 0.00037 & Accept & Congo Rep & 0.65777 & 0.00037 & Accept \\
\hline Egypt & 0.71466 & 0.00037 & Accept & Swaziland & 0.65821 & 0.00037 & Accept \\
\hline Jamaica & 0.72368 & 0.00037 & Accept & Colombia & 0.65966 & 0.00037 & Accept \\
\hline Venezuela & 0.72702 & 0.00037 & Accept & Niger & 0.67626 & 0.00037 & Accept \\
\hline Djibouti & 0.73561 & 0.00037 & Accept & Greece & 0.69267 & 0.00037 & Accept \\
\hline Iceland & 0.73854 & 0.00037 & Accept & Dominican & 0.70277 & 0.00037 & Accept \\
\hline Croatia & 0.74221 & 0.00037 & Accept & Djibouti & 0.71720 & 0.00037 & Accept \\
\hline Armenia & 0.76413 & 0.00037 & Accept & Romania & 0.72008 & 0.00037 & Accept \\
\hline Nicaragua & 0.76947 & 0.00037 & Accept & Sierra Leon & 0.73788 & 0.00037 & Accept \\
\hline Singapore & 0.77647 & 0.00037 & Accept & Argentina & 0.75688 & 0.00037 & Accept \\
\hline Zimbabwe & 0.77677 & 0.00037 & Accept & New Zealand & 0.76084 & 0.00037 & Accept \\
\hline Ghana & 0.78207 & 0.00037 & Accept & Vanuatu & 0.76264 & 0.00037 & Accept \\
\hline Senegal & 0.83143 & 0.00037 & Accept & India & 0.80901 & 0.00037 & Accept \\
\hline Kyrgyz Rep & 0.83208 & 0.00037 & Accept & Venezuela & 0.81089 & 0.00037 & Accept \\
\hline Denmark & 0.84976 & 0.00037 & Accept & Iran & 0.81999 & 0.00037 & Accept \\
\hline Belarus & 0.85270 & 0.00037 & Accept & Croatia & 0.82296 & 0.00037 & Accept \\
\hline Belize & 0.86255 & 0.00037 & Accept & Spain & 0.83109 & 0.00037 & Accept \\
\hline Austria & 0.86480 & 0.00037 & Accept & Uganda & 0.83150 & 0.00037 & Accept \\
\hline Liberia & 0.87705 & 0.00037 & Accept & Jordan & 0.83199 & 0.00037 & Accept \\
\hline Bolivia & 0.88163 & 0.00037 & Accept & South Africa & 0.85139 & 0.00037 & Accept \\
\hline Tonga & 0.88176 & 0.00037 & Accept & Rwanda & 0.85199 & 0.00037 & Accept \\
\hline Kazakhstan & 0.88276 & 0.00037 & Accept & Philippines & 0.86277 & 0.00037 & Accept \\
\hline Ivory Cost & 0.88793 & 0.00037 & Accept & Tajikistan & 0.86570 & 0.00037 & Accept \\
\hline Slovenia & 0.89119 & 0.00037 & Accept & Liberia & 0.87773 & 0.00037 & Accept \\
\hline Guatemala & 0.90013 & 0.00037 & Accept & Kuwait & 0.87907 & 0.00037 & Accept \\
\hline Barbados & 0.90073 & 0.00037 & Accept & Belgium & 0.88109 & 0.00037 & Accept \\
\hline Lesotho & 0.90329 & 0.00037 & Accept & Kyrgyz Rep & 0.88844 & 0.00037 & Accept \\
\hline Ecuador & 0.90380 & 0.00037 & Accept & Mongolia & 0.89703 & 0.00037 & Accept \\
\hline Slovak Rep & 0.90741 & 0.00037 & Accept & Hungary & 0.90669 & 0.00037 & Accept \\
\hline Italy & 0.91439 & 0.00037 & Accept & Mali & 0.92423 & 0.00037 & Accept \\
\hline Burkina Faso & 0.92351 & 0.00037 & Accept & Central Africa & 0.93305 & 0.00037 & Accept \\
\hline Czech Rep & 0.92572 & 0.00037 & Accept & Tonga & 0.95354 & 0.00037 & Accept \\
\hline Sri Lanka & 0.94118 & 0.00037 & Accept & Nepal & 0.96147 & 0.00037 & Accept \\
\hline Panama & 0.94401 & 0.00037 & Accept & Kazakhstan & 0.96584 & 0.00037 & Accept \\
\hline Philippines & 0.95820 & 0.00037 & Accept & Equatorial & 0.97720 & 0.00037 & Accept \\
\hline Pakistan & 0.96614 & 0.00037 & Accept & Cambodia & 0.97998 & 0.00037 & Accept \\
\hline Somalia & 0.96712 & 0.00037 & Accept & Israel & 0.98438 & 0.00037 & Accept \\
\hline Nepal & 0.96837 & 0.00037 & Accept & Armenia & 0.99268 & 0.00037 & Accept \\
\hline Chile & 0.99030 & 0.00037 & Accept & Belize & 0.99968 & 0.00037 & Accept \\
\hline
\end{tabular}

Table 2 notes:

The column headed Country identifies the country to which the row refers to. The column headed $\mathrm{P}_{\mathrm{j}}$ gives the probability value for each individual country's time-series GNC test arranged in ascending order of magnitude. The column headed $\frac{\alpha}{r}$ gives the nominal level of significance $(\propto=0.050)$ divided by $r$, where $r=136$ (column 3 ) and $\mathrm{r}=134$ (column 7). The column headed Decision indicates whether the GNC null should be accepted or rejected for any particular country. 
Based upon the F-test for Granger-causality from GDPG to FDIG we find that $r=136$ (see equation (12)) because the probability values, $\mathrm{P}_{\mathrm{j}}$, (column 2 of Table 2 ) are greater than $\frac{\alpha}{r}$ (with $\alpha=0.05$ ), being 0.00037 (column 3), for all 136 countries. This suggests that the null hypothesis that GDPG does not Granger-cause FDIG cannot be rejected for all countries. The F-test for Granger-causality from FDIG to GDPG indicates that $r=134$ because the probability values (column 6) are greater than 0.00037 (column 7) for 134 countries. Thus, the only two countries where there is evidence that FDIG Granger-causes GDPG are Estonia and Guyana. FDIG does not Granger-cause GDP for the remaining 134 countries.

Using the Wald test for Granger-causality from GDPG to FDIG we find that $r=136$ (column 2 and 3 of Table 3) which suggests that the null hypothesis that GDPG does not Grangercause FDIG cannot be rejected for all countries. This is consistent with the SHH results from the F-test. The Wald test for Granger-causality from FDIG to GDPG indicates that $r=133$ (column 6 and 7). Thus, for only 3 of the 136 countries is there evidence that FDIG Grangercauses GDPG being Estonia, Guyana and Poland. The only difference from the SHH F-test results is that Poland is added to the countries where there is evident Granger-causality. 
Table 3: SHH GNC test (Wald statistic)

GDPG to FDIG

FDIG to GDPG

\begin{tabular}{|c|c|c|c|c|c|c|c|}
\hline Country & $\mathrm{P}_{\mathrm{j}}$ & $\frac{\alpha}{r}$ & Decision & Country & $\mathrm{P}_{\mathrm{j}}$ & $\frac{\alpha}{r}$ & Decision \\
\hline Bangladesh & 0.00045 & 0.00037 & Accept & Estonia & 0.00000 & 0.00038 & Reject \\
\hline Oman & 0.00192 & 0.00037 & Accept & Guyana & 0.00001 & 0.00038 & Reject \\
\hline Algeria & 0.00326 & 0.00037 & Accept & Poland & 0.00010 & 0.00038 & Reject \\
\hline Niger & 0.01032 & 0.00037 & Accept & Honduras & 0.00057 & 0.00038 & Accept \\
\hline Ireland & 0.01100 & 0.00037 & Accept & Burkina Faso & 0.00150 & 0.00038 & Accept \\
\hline Kuwait & 0.01191 & 0.00037 & Accept & Algeria & 0.00276 & 0.00038 & Accept \\
\hline Iran & 0.01739 & 0.00037 & Accept & Lithuania & 0.01074 & 0.00038 & Accept \\
\hline Gabon & 0.02049 & 0.00037 & Accept & Mauritius & 0.01179 & 0.00038 & Accept \\
\hline Turkey & 0.02056 & 0.00037 & Accept & Tanzania & 0.01267 & 0.00038 & Accept \\
\hline Spain & 0.02418 & 0.00037 & Accept & El Salvador & 0.01640 & 0.00038 & Accept \\
\hline Vietnam & 0.02466 & 0.00037 & Accept & Chile & 0.01680 & 0.00038 & Accept \\
\hline Jordan & 0.02579 & 0.00037 & Accept & Guinea Bissau & 0.02061 & 0.00038 & Accept \\
\hline Norway & 0.02891 & 0.00037 & Accept & Korea Rep & 0.02638 & 0.00038 & Accept \\
\hline Kenya & 0.03274 & 0.00037 & Accept & Barbados & 0.03738 & 0.00038 & Accept \\
\hline Israel & 0.03962 & 0.00037 & Accept & Malaysia & 0.03911 & 0.00038 & Accept \\
\hline Greece & 0.04031 & 0.00037 & Accept & Finland & 0.05711 & 0.00038 & Accept \\
\hline Macedonia & 0.04375 & 0.00037 & Accept & Haiti & 0.06326 & 0.00038 & Accept \\
\hline Belgium & 0.05648 & 0.00037 & Accept & Indonesia & 0.07372 & 0.00038 & Accept \\
\hline Tunisia & 0.06536 & 0.00037 & Accept & Japan & 0.08529 & 0.00038 & Accept \\
\hline Canada & 0.07064 & 0.00037 & Accept & Lesotho & 0.09866 & 0.00038 & Accept \\
\hline Chad & 0.08279 & 0.00037 & Accept & Slovak Rep & 0.11238 & 0.00038 & Accept \\
\hline Mexico & 0.09806 & 0.00037 & Accept & Nigeria & 0.12423 & 0.00038 & Accept \\
\hline Dominican & 0.09819 & 0.00037 & Accept & Tunisia & 0.12933 & 0.00038 & Accept \\
\hline Netherlands & 0.10137 & 0.00037 & Accept & Moldova & 0.13065 & 0.00038 & Accept \\
\hline UK & 0.11250 & 0.00037 & Accept & Uzbekistan & 0.13313 & 0.00038 & Accept \\
\hline Poland & 0.12016 & 0.00037 & Accept & Congo Dem & 0.13664 & 0.00038 & Accept \\
\hline South Africa & 0.13329 & 0.00037 & Accept & Guinea & 0.15794 & 0.00038 & Accept \\
\hline Colombia & 0.13960 & 0.00037 & Accept & Gabon & 0.17202 & 0.00038 & Accept \\
\hline Haiti & 0.14539 & 0.00037 & Accept & Iceland & 0.18098 & 0.00038 & Accept \\
\hline Tajikistan & 0.14726 & 0.00037 & Accept & Mauritania & 0.19042 & 0.00038 & Accept \\
\hline Madagascar & 0.15128 & 0.00037 & Accept & Nicaragua & 0.19605 & 0.00038 & Accept \\
\hline Central Africa & 0.16188 & 0.00037 & Accept & Macedonia & 0.21077 & 0.00038 & Accept \\
\hline Vanuatu & 0.16317 & 0.00037 & Accept & Cyprus & 0.21612 & 0.00038 & Accept \\
\hline Lithuania & 0.16564 & 0.00037 & Accept & Grenada & 0.21894 & 0.00038 & Accept \\
\hline Burundi & 0.17403 & 0.00037 & Accept & Italy & 0.22653 & 0.00038 & Accept \\
\hline USA & 0.19048 & 0.00037 & Accept & Jamaica & 0.23564 & 0.00038 & Accept \\
\hline China & 0.20349 & 0.00037 & Accept & Germany & 0.24658 & 0.00038 & Accept \\
\hline Indonesia & 0.20593 & 0.00037 & Accept & Portugal & 0.24860 & 0.00038 & Accept \\
\hline Uzbekistan & 0.20887 & 0.00037 & Accept & Egypt & 0.25185 & 0.00038 & Accept \\
\hline El Salvador & 0.21352 & 0.00037 & Accept & Togo & 0.25218 & 0.00038 & Accept \\
\hline Brazil & 0.21834 & 0.00037 & Accept & Uruguay & 0.25441 & 0.00038 & Accept \\
\hline Mozambique & 0.22750 & 0.00037 & Accept & Senegal & 0.26532 & 0.00038 & Accept \\
\hline Guyana & 0.22905 & 0.00037 & Accept & Singapore & 0.27201 & 0.00038 & Accept \\
\hline Mongolia & 0.23170 & 0.00037 & Accept & USA & 0.28374 & 0.00038 & Accept \\
\hline Moldova & 0.23284 & 0.00037 & Accept & France & 0.28809 & 0.00038 & Accept \\
\hline Argentina & 0.24926 & 0.00037 & Accept & Syria & 0.29008 & 0.00038 & Accept \\
\hline Portugal & 0.29042 & 0.00037 & Accept & Netherland & 0.29440 & 0.00038 & Accept \\
\hline
\end{tabular}


Table 3: SHH GNC test (Wald statistic) continued

\begin{tabular}{|c|c|c|c|c|c|c|c|}
\hline \multicolumn{4}{|c|}{ GDPG to FDIG } & \multicolumn{4}{|c|}{ FDIG to GDPG } \\
\hline Country & $\mathrm{P}_{\mathrm{j}}$ & $\frac{\alpha}{r}$ & Decision & Country & $\mathrm{P}_{\mathrm{j}}$ & $\frac{\propto}{r}$ & Decision \\
\hline Ethiopia & 0.32046 & 0.00037 & Accept & Mexico & 0.30118 & 0.00038 & Accept \\
\hline Romania & 0.34295 & 0.00037 & Accept & Czech Rep & 0.30150 & 0.00038 & Accept \\
\hline Australia & 0.35470 & 0.00037 & Accept & Sweden & 0.31071 & 0.00038 & Accept \\
\hline Japan & 0.37102 & 0.00037 & Accept & Canada & 0.32418 & 0.00038 & Accept \\
\hline Thailand & 0.38820 & 0.00037 & Accept & Turkey & 0.32661 & 0.00038 & Accept \\
\hline Morocco & 0.38825 & 0.00037 & Accept & Ireland & 0.32854 & 0.00038 & Accept \\
\hline Sierra Leon & 0.39193 & 0.00037 & Accept & Burundi & 0.33265 & 0.00038 & Accept \\
\hline Mauritius & 0.39605 & 0.00037 & Accept & Zimbabwe & 0.34266 & 0.00038 & Accept \\
\hline Nigeria & 0.39684 & 0.00037 & Accept & Austria & 0.35098 & 0.00038 & Accept \\
\hline Congo Rep & 0.39801 & 0.00037 & Accept & Peru & 0.35156 & 0.00038 & Accept \\
\hline Guatemala & 0.40738 & 0.00037 & Accept & Morocco & 0.37173 & 0.00038 & Accept \\
\hline India & 0.41138 & 0.00037 & Accept & Pakistan & 0.37204 & 0.00038 & Accept \\
\hline Honduras & 0.41450 & 0.00037 & Accept & Panama & 0.37327 & 0.00038 & Accept \\
\hline Hungary & 0.41495 & 0.00037 & Accept & Costa Rica & 0.37419 & 0.00038 & Accept \\
\hline Benin & 0.44793 & 0.00037 & Accept & Ecuador & 0.38312 & 0.00038 & Accept \\
\hline Estonia & 0.47058 & 0.00037 & Accept & Guatemala & 0.38788 & 0.00038 & Accept \\
\hline Angola & 0.47228 & 0.00037 & Accept & Brazil & 0.39960 & 0.00038 & Accept \\
\hline Malaysia & 0.47580 & 0.00037 & Accept & Chad & 0.39960 & 0.00038 & Accept \\
\hline Malawi & 0.47708 & 0.00037 & Accept & Ivory Cost & 0.39993 & 0.00038 & Accept \\
\hline Mauritania & 0.47889 & 0.00037 & Accept & UK & 0.40467 & 0.00038 & Accept \\
\hline Botswana & 0.49474 & 0.00037 & Accept & Norway & 0.41208 & 0.00038 & Accept \\
\hline Swaziland & 0.50100 & 0.00037 & Accept & Angola & 0.42295 & 0.00038 & Accept \\
\hline Korea Rep & 0.50523 & 0.00037 & Accept & Sri Lanka & 0.43117 & 0.00038 & Accept \\
\hline New Zealand & 0.53494 & 0.00037 & Accept & Bolivia & 0.44049 & 0.00038 & Accept \\
\hline Cyprus & 0.54970 & 0.00037 & Accept & Ghana & 0.44495 & 0.00038 & Accept \\
\hline Zambia & 0.56862 & 0.00037 & Accept & Mozambique & 0.45733 & 0.00038 & Accept \\
\hline Fiji & 0.57331 & 0.00037 & Accept & Yemen & 0.45854 & 0.00038 & Accept \\
\hline Yemen & 0.57419 & 0.00037 & Accept & Denmark & 0.46618 & 0.00038 & Accept \\
\hline Uganda & 0.59876 & 0.00037 & Accept & Slovak Rep & 0.46626 & 0.00038 & Accept \\
\hline Uruguay & 0.60340 & 0.00037 & Accept & Malawi & 0.46895 & 0.00038 & Accept \\
\hline Equatorial & 0.61558 & 0.00037 & Accept & Switzerland & 0.47573 & 0.00038 & Accept \\
\hline France & 0.61599 & 0.00037 & Accept & Ethiopia & 0.50684 & 0.00038 & Accept \\
\hline Peru & 0.62676 & 0.00037 & Accept & Vietnam & 0.50807 & 0.00038 & Accept \\
\hline Bulgaria & 0.63171 & 0.00037 & Accept & Oman & 0.50819 & 0.00038 & Accept \\
\hline Switzerland & 0.63730 & 0.00037 & Accept & Fiji & 0.50897 & 0.00038 & Accept \\
\hline Syria & 0.65138 & 0.00037 & Accept & Kenya & 0.51703 & 0.00038 & Accept \\
\hline Sudan & 0.65486 & 0.00037 & Accept & Botswana & 0.51795 & 0.00038 & Accept \\
\hline Rwanda & 0.66037 & 0.00037 & Accept & Zambia & 0.51963 & 0.00038 & Accept \\
\hline Costa Rica & 0.66692 & 0.00037 & Accept & Paraguay & 0.52542 & 0.00038 & Accept \\
\hline Congo Dem & 0.66833 & 0.00037 & Accept & Albania & 0.52805 & 0.00038 & Accept \\
\hline Guinea Bissau & 0.66948 & 0.00037 & Accept & China & 0.54117 & 0.00038 & Accept \\
\hline Guinea & 0.66978 & 0.00037 & Accept & Australia & 0.54527 & 0.00038 & Accept \\
\hline Albania & 0.67074 & 0.00037 & Accept & Bangladesh & 0.56733 & 0.00038 & Accept \\
\hline Cambodia & 0.67098 & 0.00037 & Accept & Thailand & 0.58201 & 0.00038 & Accept \\
\hline Tanzania & 0.68490 & 0.00037 & Accept & Madagascar & 0.60018 & 0.00038 & Accept \\
\hline Paraguay & 0.68859 & 0.00037 & Accept & Sudan & 0.60908 & 0.00038 & Accept \\
\hline
\end{tabular}


Table 3 : SHH GNC test (Wald statistic) continued

\begin{tabular}{|c|c|c|c|c|c|c|c|}
\hline \multicolumn{4}{|c|}{ GDPG to FDIG } & \multicolumn{4}{|c|}{ FDIG to GDPG } \\
\hline Country & $\mathrm{P}_{\mathrm{j}}$ & $\frac{\alpha}{r}$ & Decision & Country & $\mathrm{P}_{\mathrm{j}}$ & $\frac{\alpha}{r}$ & Decision \\
\hline Finland & 0.68865 & 0.00037 & Accept & Somalia & 0.63350 & 0.00038 & Accept \\
\hline Sweden & 0.69078 & 0.00037 & Accept & Belarus & 0.63741 & 0.00038 & Accept \\
\hline Mali & 0.69561 & 0.00037 & Accept & Bulgaria & 0.64540 & 0.00038 & Accept \\
\hline Togo & 0.69805 & 0.00037 & Accept & Benin & 0.65089 & 0.00038 & Accept \\
\hline Germany & 0.70456 & 0.00037 & Accept & Congo Rep & 0.65476 & 0.00038 & Accept \\
\hline Egypt & 0.71223 & 0.00037 & Accept & Swaziland & 0.65500 & 0.00038 & Accept \\
\hline Jamaica & 0.72135 & 0.00037 & Accept & Colombia & 0.65549 & 0.00038 & Accept \\
\hline Venezuela & 0.72471 & 0.00037 & Accept & Niger & 0.67344 & 0.00038 & Accept \\
\hline Djibouti & 0.73297 & 0.00037 & Accept & Dominican & 0.68997 & 0.00038 & Accept \\
\hline Iceland & 0.73439 & 0.00037 & Accept & Greece & 0.69002 & 0.00038 & Accept \\
\hline Croatia & 0.74004 & 0.00037 & Accept & Romania & 0.71369 & 0.00038 & Accept \\
\hline Armenia & 0.75839 & 0.00037 & Accept & Djibouti & 0.71436 & 0.00038 & Accept \\
\hline Nicaragua & 0.76729 & 0.00037 & Accept & Sierra Leon & 0.73568 & 0.00038 & Accept \\
\hline Singapore & 0.77450 & 0.00037 & Accept & Argentina & 0.75428 & 0.00038 & Accept \\
\hline Zimbabwe & 0.77492 & 0.00037 & Accept & New Zealand & 0.75857 & 0.00038 & Accept \\
\hline Ghana & 0.78016 & 0.00037 & Accept & Vanuatu & 0.75977 & 0.00038 & Accept \\
\hline Senegal & 0.83007 & 0.00037 & Accept & India & 0.80709 & 0.00038 & Accept \\
\hline Kyrgyz Rep & 0.83020 & 0.00037 & Accept & Venezuela & 0.80935 & 0.00038 & Accept \\
\hline Denmark & 0.84587 & 0.00037 & Accept & Iran & 0.81854 & 0.00038 & Accept \\
\hline Belarus & 0.85124 & 0.00037 & Accept & Croatia & 0.82153 & 0.00038 & Accept \\
\hline Belize & 0.86124 & 0.00037 & Accept & Uganda & 0.82837 & 0.00038 & Accept \\
\hline Austria & 0.86372 & 0.00037 & Accept & Spain & 0.82947 & 0.00038 & Accept \\
\hline Liberia & 0.87580 & 0.00037 & Accept & Jordan & 0.83024 & 0.00038 & Accept \\
\hline Tonga & 0.88008 & 0.00037 & Accept & South Africa & 0.85020 & 0.00038 & Accept \\
\hline Bolivia & 0.88070 & 0.00037 & Accept & Rwanda & 0.85079 & 0.00038 & Accept \\
\hline Kazakhstan & 0.88162 & 0.00037 & Accept & Philippines & 0.86168 & 0.00038 & Accept \\
\hline Ivory Cost & 0.88704 & 0.00037 & Accept & Tajikistan & 0.86223 & 0.00038 & Accept \\
\hline Slovenia & 0.88842 & 0.00037 & Accept & Liberia & 0.87648 & 0.00038 & Accept \\
\hline Guatemala & 0.89904 & 0.00037 & Accept & Kuwait & 0.87787 & 0.00038 & Accept \\
\hline Barbados & 0.89924 & 0.00037 & Accept & Belgium & 0.87803 & 0.00038 & Accept \\
\hline Lesotho & 0.90139 & 0.00037 & Accept & Kazakhstan & 0.88720 & 0.00038 & Accept \\
\hline Ecuador & 0.90305 & 0.00037 & Accept & Mongolia & 0.90137 & 0.00038 & Accept \\
\hline Slovak Rep & 0.91125 & 0.00037 & Accept & Hungary & 0.90593 & 0.00038 & Accept \\
\hline Italy & 0.91371 & 0.00037 & Accept & Mali & 0.92362 & 0.00038 & Accept \\
\hline Czech Rep & 0.92498 & 0.00037 & Accept & Central Africa & 0.93253 & 0.00038 & Accept \\
\hline Burkina Faso & 0.92731 & 0.00037 & Accept & Tonga & 0.95292 & 0.00038 & Accept \\
\hline Sri Lanka & 0.94074 & 0.00037 & Accept & Nepal & 0.96103 & 0.00038 & Accept \\
\hline Panama & 0.94358 & 0.00037 & Accept & Kazakhstan & 0.96547 & 0.00038 & Accept \\
\hline Philippines & 0.95790 & 0.00037 & Accept & Equatorial & 0.97696 & 0.00038 & Accept \\
\hline Pakistan & 0.96590 & 0.00037 & Accept & Cambodia & 0.97977 & 0.00038 & Accept \\
\hline Somalia & 0.96663 & 0.00037 & Accept & Israel & 0.98414 & 0.00038 & Accept \\
\hline Nepal & 0.96803 & 0.00037 & Accept & Armenia & 0.99252 & 0.00038 & Accept \\
\hline Chile & 0.99016 & 0.00037 & Accept & Belize & 0.99968 & 0.00038 & Accept \\
\hline
\end{tabular}

Table 3 notes:

See notes to Table 2 except $r=136($ column 3$)$ and $r=133$ (column 7). 


\section{Conclusion}

The main objective of our work is to investigate the issue of causality across a sample of 136 diverse countries for the period 1970 - 2006 by applying time-series and panel Grangercausality tests based on Hurlin (2004), Fisher (1948), Sims (1986), Hommel (1988) and Hanck (2013). As argued, the data set is larger than previous similar studies and the methods are the most advanced and general available. In particular, they can accommodate heterogeneous intercepts and slopes, thus allowing us to make country-by-country inferences and not make possibly erroneous generalised inferences across the cross-section. We argue that this is an appropriate approach in view of the disparate and conflicting results of existing empirical studies.

The results can be summarised as follows. According to the Hurlin and Fisher panel tests FDIG unambiguously Granger-causes GDPG for at least one country. However, the results from these tests are ambiguous regarding whether GDPG Granger-causes FDIG for at least one country. Using Hanck's (2013) panel test we are able to determine whether and for which countries there is Granger-causality. This test suggests that at most there are three countries (Estonia, Guyana and Poland) where FDIG Granger-causes GDPG and no countries where GDPG Granger-causes FDIG. The results from Hanck's (2013) panel test are broadly consistent with those based on Fisher (1948) and Hurlin (2004a), however, the former are illuminating in that they suggest that there is evidence of Granger-causality for very few of the 136 countries. We regard the panel tests as more reliable than the individual time-series tests, which also suggest evidence of Granger-causality for relatively few countries (if more than is indicated by the panel tests).

We note that the three countries where there is evident Granger-causality from FDIG to GDPG according to Hanck's (2013) test have different histories of macroeconomic episodes, policy regimes and growth patterns. For instance, according to the World Bank, Estonia and Poland are European economies in transition which have policy decisions that attract even more FDI and their locations and growth prospects thus favour them.

Our finding that in only 3 out of 136 countries is there significant Granger-causality from FDIG to GDPG suggests that there is no impact of FDI on economic growth for virtually all countries. However, it maybe that the share of FDI inflows to GDP have been quantitatively 
too small to have a high and significant impact on economic growth or that the relationship between the two variables is too complex to be identified in a bivariate Granger-causality framework. Further, the relationship between FDI and economic growth may well depend on the determinants of FDI. If the determinants have a strong link with growth in the host country growth may be found to cause FDI, while output may grow faster when FDI takes place under other circumstances.

Overall, the empirical evidence reported in this paper would lend support to a conclusion that there is no causality between FDI inflows and economic growth in either direction (excepting 3 countries out of 136). Thus, while there is much attention in policy and academia on FDI, our evidence questions whether FDI is related with the growth process.

\section{References}

Agrawal, P. (2000) Economic impact of foreign direct investment in south Asia Mimeo. Bombay: Indira Gandhi Institute of Development Research, Gen. A.K. Bombay; India

Alfaro, L., Chanda, A., Kalemli-Ozcan, S. and Sayek, S. (2004). "FDI and economic growth: The role of local financial markets", Journal of International Economics, 64, 89-112.

Asiedu, E. (2002). "On the Determinants of Foreign Direct Investment to Developing Countries: Is Africa Different?". World Development, 30 (1): 107-19.

Asiedu, E. (2003). "Policy Reform and Foreign Direct Investment to Africa: Absolute Progress but Relative Decline". Development Policy Review, 2004, 22 (1), 41-48.

Blomstrom M., Lipsey, R.E and Zejan, M., (1996). Is Fixed Investment the Key to Economic Growth? Quarterly Journal of Economics, No. 111, 269-276.

Blomström, M., Kokko, A., and M. Zejan (1992). "Host Country Competition and Technology Transfer by Multinationals" NBER Working Papers 4131, National Bureau of Economic Research, Inc.

Blomström, M., Lipsey, R.E. and Zejan, M. (1996). "Is Fixed Investment the Key to Economic Growth?," The Quarterly Journal of Economics, Oxford University Press, vol. 111(1), 269-276.

Borenztein,E., DeGregorio, J. and Lee, J. W. (1998). "How does foreign direct investment affect economic growth", Journal of International Economics, 45, 115-135.

Busse, M. and Groizard, J.L. (2008). "FDI, Regulations and Growth", The World Economy,31(7),861-886.

Cairo, Egypt.

Campos, N. F. and Kinoshita, Y. (2002). "Foreign Direct Investment as Technology Transferred: Some Panel Evidence from the Transition Economies." Manchester School, 2002, 70, (3), 398-419.

Carkovic, M., and R. Levine. 2005. Does Foreign Direct Investment Accelerate Economic Growth? in T.H. Moran, E.M. Graham, and M. Blomstrom. Does Foreign Direct Investment Promote Development? Washington, DC: Institute for International Economics and Center for Global Development. Washington, DC, 195-220.

Caves R. (1996): Multinational enterprises and Economic analysis. $2^{\text {nd }}$ edition. Cambridge. 
MA Cambridge University Press

Chakrabarti, A. (2001) The Determinants of Foreign Direct Investment: Sensitivity Analyses of Cross-Country Regressions, Kyklos. 54(1): 89-113.

Chakraborty, C., and Basu, P., (2002). Foreign Direct Investment and growth in India: a cointegration approach, Applied Economics No. 34, pp. 1061-1073.

Chan V. (2000): "Foreign Direct Investment and Economic Growth in Taiwan's Manufacturing Industries"; in Kruger K. and Takatoshi I. (eds.): The Role of FDI in East Asia Economic Development; Chicago Press.

Chanegriha, M., Stewart, C, Tsoukis C. (2017): Identifying the robust economic, geographical and political determinants of FDI: an Extreme Bounds Analysis, Empirical Economics, 52, 2 (March), 759-776.

Choe, J.I. (2003). "Do foreign direct investment and gross domestic investment promote economic growth?", Review of Development Economics, 7, 44-57.

Chowdhury, A., and Mavrotas, G., (2005). FDI and Growth: A Causal Relationship, United Nations University, WIDER, Research Paper No: 2005/25.

De Mello, Jr., L. R. (1997), Foreign Direct Investment in Developing Countries and Growth: ASelective Survey, Journal of Development Studies, 34(1), 1-34.

De Mello, L. F., Jr., "Foreign Direct Investment-led Growth: Evidence from time Series and Panel Data," Oxford Economic Papers, 51(1), 1999, pp.133-151.

Duttaray, M. (2001). "Essays on Foreign Direct Investment and Growth: Causality and Mechanism".

Ericsson, J., and Irandoust, M., (2001). On the Causality between Foreign Direct Investment and Output: A Comparative Study, The International Trade Journal, Volume 15(1), 1-26.

Fisher, R.A. (1948), Combining Independent Tests of Significance, American Statistician, Vol. 2, 30.

Fisher, R.A.(1932). Statistical Methods for Research Workers, $4^{\text {th }}$ Edition. Oliver \& Boyd Edinburgh.

Gao, T. (2005),Foreign direct investment and growth under economic integration, journal of international economics,67,p157-174.

Ghosh and Wang (2009). Does FDI accelerate economic growth? Global Economy Journal, $9(4), 1-21$.

Gorg, H., and D. Greenaway (2004). 'Much Ado about Nothing? Do Domestic Firms Really Benefit from Foreign Direct Investment?'. World Bank Research Observer, 19: 171-97.

Greene, William H. 2000. Econometric analysis. 4th ed. Englewood Cliffs, NJ: Prentice-Hall International.

Gursoy, F., A. Sekreter and H. Kalyoncu, 2013.FDI and economic growth relationship based on cross-country comparison. International Journal of Economics and Financial Issues, 3(2): 519-524.

Hanck C. (2008). "An Intersection Test for Panel Unit Roots", Mimeo, Department of Economics, University of Dortmund.

Hanck, C. (2013). An intersection test for panel unit roots. Econometric Reviews, 32(2):183203.

Hommel G (1988). "A Stagewise Rejective Multiple Test Procedure Based on a Modified Bonferroni Test",Biometrika, 75, 2, 383-386.

Hood III, M.V., Q. Kidd and I. L. Morris (2008), “Two Sides of the Same Coin? Employing Grange Causality Tests in a Time Series Cross-Section Framework," Political Analysis 16: 324-344.

Hurlin C. (2001), A note on causality tests in panel data models with random coefficient, Mimeo.

Hurlin, C. (2004a), “Testing Granger Causality in Heterogeneous Panel Data Models with 
Fixed Coefficients", Miméo, University Orléans.

Hurlin, C. (2004b), "A Note on Causality Tests in Panel Data Models with Random Coefficients", Miméo, University Orléans.

Hurlin, C. and Venet, B. (2001) "Granger Causality Tests in Panel Data Models with Fixed Coefficients", Miméo, University Paris IX.

Hurlin, C., 2008., Testing for Granger Non-causality in Heterogeneous Panels, Working Paper LEO, Université d.Orléans, 2007-10.

Lensink, R., and Morrissey, O. (2006). Foreign Direct Investment: Flows, Volatility, and the Impact on Growth, Review of International Economics, 14(3), 478-493.

Mencinger, J., (2003). "Does Foreign Direct Investment Always Enhance Economic Growth?", Kyklos, 56(4), 491-509.

OECD (2002). "Foreign direct investment for development: Maximising benefits, minimizing costs", OECD publishing, Paris.

Ozturk, I. Foreign Direct Investment-Growth Nexus: A Review of the recent Literature, International Journal of Applied Econometrics and Quantitative Studies, 4(2), 79-98.

Ozturk, I., Kalyoncu, H. (2007), Foreign Direct Investment and Growth: An Empirical Investigation Based on Cross-Country Comparison, Economia Internazionale, 60(1), 7582.

Simes, R. J. (1986). "An improved Bonferroni Procedure for Multiple Tests of significance",Biometrika, 73, 3, 751-754.

Sooreea-Bheemul, B. and R. Sooreea, 2013.Missing causality links between foreign direct investment, exports, domestic investment and economic growth. International Journal of Business and Emerging Markets, 5(4): 322-340.

Zhang, Kevin Honglin, 2001. "How does Foreign Direct Investment affect Economic Growth in China?" Economics of Transition, 9 (3): 679-693. 